\title{
Morphodynamics of prograding beaches: A synthesis of seasonal- to century-scale observations of the Columbia River littoral cell
}

\author{
Peter Ruggiero $^{1 *}$, George M. Kaminsky ${ }^{2}$, Guy Gelfenbaum ${ }^{3}$, Nicholas Cohn ${ }^{1}$ \\ Invited review manuscript submitted to: Marine Geology \\ ${ }^{1}$ College of Earth, Ocean, and Atmospheric Sciences, Oregon State University, Corvallis, OR, \\ 97331, USA; voice: 541-737-1239, fax: 541-737-1200, \\ *Corresponding author \\ pruggier@coas.oregonstate.edu \\ ${ }^{2}$ Washington State Department of Ecology, Coastal Monitoring \& Analysis Program, \\ Olympia, WA, 98504, USA; voice: 360-407-6797, gkam461@ecy.wa.gov \\ ${ }^{3}$ U.S. Geological Survey, Pacific Coastal and Marine Science Center, 400 Natural Bridges \\ Drive, Santa Cruz, CA 95060, voice: 831-460-7417, ggelfenbaum@usgs.gov
}




\section{Abstract}

Findings from nearly two decades of research focused on the Columbia River littoral cell (CRLC), a set of rapidly prograding coastal barriers and strand-plains in the U.S. Pacific Northwest, are synthesized to investigate the morphodynamics associated with prograding 
morphodynamics; progradation; sediment budget

\section{Introduction}

Coastal evolution results from the cumulative effects of typically small residual differences between relatively large gross signals. In light of recent projections of sea-level rise over the next several decades to century (e.g., NRC, 2012 and IPCC, 2014), there is an increasingly important need for accurate forecasts of net seasonal- to century-scale coastal change. At present, however, our understanding of the processes responsible for storm-induced beach erosion and coastal retreat, while certainly incomplete, has far outpaced our knowledge of coastal recovery and beach, dune, and barrier building during fair-weather periods. As it is unclear whether some transgressive barrier islands can even be maintained under projected scenarios of accelerating sea-level rise (e.g., Riggs and Ames, 2003), regressive barriers may become increasingly populated and developed due to their perceived resilience to projected changes in forcing conditions.

The interaction of nonlinear processes operating over the range of scales relevant to coastal stewardship makes prediction of seasonal- to century-scale coastal change difficult. Most studies have tended to focus on specific time scales, such as event-scale erosion via processes and modeling studies (e.g., Roelvink et al., 2009) or decadal-scale coastal change via desktop shoreline change studies (e.g., Hapke et al., 2006), and specific morphological units, such as the nearshore bar zone (e.g., Ruessink et al., 2003) or coastal dunes (e.g., Duran and Moore, 2013) (Figure 1). In contrast, few studies have explored the contiguity between morphological units involving multiple spatial and temporal scales. Aagaard et al. (2004) point out the apparent inconsistency between large scale coastal behavior (LSCB) studies that have explained barrier formation through onshore-directed sediment transport from the lower shoreface to the barrier (e.g., Cowell et al., 1995; Stive and de Vriend, 1995) and processbased models that typically predict a net export of sand from the beach to the shoreface via 
net offshore-directed currents (Roelvink et al., 2009). Cowell et al. (2003a,b) introduced the coastal tract concept as a framework for aggregation of processes in modeling century to millennial scale coastal change. However, few studies (e.g., Aagaard et al., 2004; Aagaard et al., 2014) have explicitly attempted to link event-scale processes with management-scale coastal evolution.

The inability to integrate over multiple scales and processes relevant to coastal evolution can have significant implications for the management of coastal barriers. As one example, there has been considerable scientific debate regarding the stability of the western end of the Fire Island National Seashore (New York, U.S.A.), a $50 \mathrm{~km}$ long barrier island predominantly managed by the U.S. National Park Service (NPS). Of concern is the source of approximately $200,000 \mathrm{~m}^{3} / \mathrm{yr}$ of sand needed to balance the sediment budget and the associated implications for sediment sourcing for beach nourishment. Geologic evidence (Schwab et al., 2000; Hapke et al., 2010; Schwab et al., 2013) suggests that an onshore flux of sediment from the continental shelf is sufficient to maintain island stability and promote spit growth even if the process has not been directly measured. Kana et al. (2011) point out that the 'possibility' that this deep-water source of sand is significant and persistent at decadal to century time scales has led to a reluctance by NPS to mine deep-water shoals for beach nourishment of Fire Island. Using a suite of engineering analyses (e.g., depth of closure, grain size distributions, etc.), Kana et al. (2011) argue that evidence for an onshore flux of sediment is lacking and the reluctance to mine the offshore for beach nourishment is unfounded. While Schwab et al. (2013) conclude that shoreface attached sand ridges provide a mechanism for onshore transport, the details regarding the physical processes controlling the cross-shelf component of sediment flux remain unknown. This example, among many others, highlights deficiencies in coastal dynamics knowledge and emphasizes a need to 
better understand the integration of physical processes that leads to long-term coastal evolution.

Studies of the interaction between waves and the seabed emphasize the influence of wave shape on bed shear stress, onshore sediment transport, and subsequent morphological change. Wave velocity skewness (relatively sharp crests and broad, flat troughs) and acceleration-skewness (saw tooth shaped, pitched forward waves with steep front faces and gently sloping rear faces) are hypothesized to drive a net onshore sediment flux. Thornton et al. (1996) demonstrated in the field that the dominant transport mechanism outside the surf zone is wave velocity skewness driving onshore transport. Waves become increasingly asymmetric as they propagate towards shore and, prior to breaking, produce strong flow accelerations under the steep leading face of the waves. An energetics-type sediment transport model (Hoefel and Elgar, 2003) suggests that onshore bar migration, observed when incident wave energy is low to moderate and mean currents are relatively weak, is related to cross-shore gradients in the acceleration skewness. More recent field studies suggest that period-averaged boundary layer streaming and onshore mass transport (Lagrangian drift) may also produce onshore-directed cross-shore sediment transport (Aagaard et al., 2012), even in non-storm conditions when depth-averaged currents are directed offshore. Further, recent advances in numerical modeling of the turbulent bottom boundary layer (Fuhrman et al., 2013; Kranenburg et al., 2013) suggest that boundary layer streaming effects can enhance onshore sediment transport rates by as much as a factor of two and can reverse the predicted direction of fine grained sediment transport beneath nonlinear waves.

These wave-driven processes are some of the mechanisms that transport sediment from the shoreface and outer surf zone to the inner surf zone. However, for beaches, dunes, and barriers to prograde, sediment must be exchanged between the subtidal - through the intertidal - to the supratidal (Figure 1), where it is ultimately available for possible transport 
by wind. However, since few studies have examined both wave and aeolian processes together, our understanding of the mechanisms that allow for beach and dune building, including recovery phases following erosive storm events, remains particularly poor. One important delivery mechanism from the nearshore to the subaerial beach is the welding of intertidal sandbars to the shoreline (e.g., Aagaard et al., 2004; and Houser, 2009). Under certain calm wave conditions intertidal bars tend to migrate through the swash zone and weld to the shoreline, directly supplying sediment from the nearshore to the dry beach (e.g., Kroon, 1994, Wijnberg and Kroon, 2002, Houser and Greenwood, 2003, Shand and Bailey, 1999, Cohn et al., 2015). Observed intertidal sandbar migration rates range from 1-10 m/day and, when environmental conditions are conducive, these features eventually completely weld to the shoreline whereupon they become no longer distinguishable from the surrounding landform (Masselink et al., 2006). Unfortunately, the importance of intertidal sandbar welding events to both short- and long-term coastal evolution has been relatively poorly detailed and only a few quantitative studies exist with the studies of Aagaard et al. (2004), Anthony et al. (2006), and Davidson-Arnott (1988) being significant exceptions. . Coastal dunes provide critical ecosystem services (e.g., Barbier et al. 2011) as they are the first line of defense against flooding (e.g., Sallenger 2000, Seabloom et al. 2013), they provide conservation value for native species (Gutierrez et al. 2012), and they are an important draw for recreation (Guerry et al. 2012). The building of coastal dunes requires sufficient sediment availability, appropriate environmental conditions for aeolian processes, including mobilization by wind through surface creep, saltation, and suspension, and an obstruction to aeolian sediment transport by vegetation (Hesp, 1984). Within the intertidal zone, moisture content plays a large role in influencing rates of aeolian transport, while the presence of vegetation in the backshore reduces bed shear stress and modulates transport rates on the dry back beach (Houser and Ellis, 2013; Duran and Moore, 2013). Other factors 
such as precipitation, ground water, and beach slope (de Vries et al., 2014) can also influence the cross-shore flux of wind-blown sediment (Anthony et al., 2006). In general, field studies indicate that sediment transport rates by cross-shore winds are near zero at the water line and increase toward the upper beach (Bauer and Davison-Arnott, 2002). Given a sufficiently long fetch for a given wind speed, a saltation saturation point is reached with a maximum potential delivery to the foredunes. Field data has also demonstrated that the intertidal zone is the largest source of sediment to the backshore (de Vries et al., 2014) and therefore many beaches are supply limited rather than transport limited (Houser, 2009). Furthermore, conceptual beach-dune interaction models, like that of Psuty (1986), suggest that when the beach sediment budget is positive (high rates of shoreline progradation) new incipient foredunes develop seaward of the existing foredune ridge limiting further vertical growth of existing dunes. Therefore both the rate and form of dune growth/recovery is closely linked with sediment availability within the intertidal zone.

Successful integration of small-scale intra-wave and aeolian processes to predict LSCB (seasons to centuries) remains a challenge due to the nonlinear behavior of coastal systems, the range of possible morphodynamic responses (both forced and free) to a stochastic environmental forcing (de Vriend, 1998), as well as due to a combination and interaction of processes occurring over a large range of time and space scales (e.g., Murray et al., 2014). These difficulties suggest that a combination of approaches, both field-based and model-based, extending over a range of time and space scales and across morphological unit boundaries is necessary to improve our understanding of coastal evolution. A recent effort by Aagaard (2014) attempting to bridge the gap between process knowledge and long-term coastal evolution via a relatively simple, yet elegant model for sediment supply from the lower shoreface to the upper shoreface is contributing to this cause. 

synthesize findings from nearly two decades of research on the Columbia River littoral cell (e.g., Gelfenbaum and Kaminsky, 2010), a set of rapidly prograding barriers and strand-plains in the U.S. Pacific Northwest (PNW, Figure 2). First, we describe the study site, its long-term evolution, and the methods used in characterizing and modeling the seasonal- to centuryscale coastal evolution. Next, we examine the observed variability and change within key morphological units including the shoreface, the nearshore bar zone, the beach, and the foredunes. While describing the units individually we attempt to connect findings at this particular study site with advances from the recent literature. We speculate on the relative role of cross-shore and alongshore processes responsible for observed sediment accumulation through the use of a simple sediment budget and morphological change models. We conclude by synthesizing our knowledge of the morphodynamics of prograding beaches over a range of time scales. Throughout this paper, we emphasize the importance of sediment supply and quantitative knowledge of sediment flux pathways in determining seasonal- to century scale coastal evolution.

\section{The Columbia River littoral cell}

The Columbia River littoral cell (CRLC) extends approximately $165 \mathrm{~km}$ between Tillamook Head, Oregon and Point Grenville, Washington (Figure 2) and consists of four concaveshaped prograded barrier plain sub-cells separated by the Columbia River, Willapa Bay, and Grays Harbor estuaries (Figure 3). The CRLC is the only extensive stretch of shoreline on the U.S. west coast that has naturally accumulated sufficient sand volumes for the beach to advance seaward (Figures 2 and 3). The modern barriers and strand-plains of the CRLC built up sequentially following the filling of the shelf and estuary accommodation space, and the slowing of relative sea-level rise approximately 6,000 years ago (Peterson et al., 2010a). Approximately 4,500 years ago, Long Beach and Clatsop Plains began to prograde, whereas 
the Grayland Plains began to prograde about 2,800 years ago. The oldest portions of the North Beach sub-cell, relatively far from the mouth of the Columbia River, began prograding 2,500 years ago (Peterson et al., 2010b).

The CRLC is situated along the active tectonic margin of the Cascadia Subduction Zone (CSZ) that produces large earthquakes (magnitude $>=8$ ), episodic events that cause tsunamis, co-seismic coastal subsidence of 0.5 to $2.5 \mathrm{~m}$ (Atwater, 1996), and shoreline retreat up to a few hundred meters per event (Doyle, 1996; Peterson et al., 2000). The last such CSZ event took place on 26 January 1700 and this paper focuses on barrier progradation subsequent to this event. Alongshore varying rates of inter-seismic vertical land motions result in alongshore varying rates of relative sea-level rise (RSLR) throughout the PNW. Within the CRLC, RSLR rates range from near stable in the Clatsop Plains sub-cell to approximately 1.0-2.0 mm/yr as reported at the Toke Point tide gage in Willapa Bay (Komar et al., 2011).

Wide, gently sloping fine sand beaches characterize the regressive CRLC barriers with sand having been derived mainly from the Columbia River. Broad surf zones with multiple sandbars typify the modally dissipative (Wright and Short, 1983; Ruggiero et al., 2005; Di Leonardo and Ruggiero, 2015), high-energy (Allan and Komar, 2002, 2006; Ruggiero et al., 2010a), meso-tidal system. Coastal foredunes back approximately $85 \%$ of the CRLC beaches (Cooper, 1958; Woxell, 1998; Hacker et al., 2012) while coastal bluffs and cliffs back the beaches along the northern half of the North Beach sub-cell (Figures 2 and 3). The construction of entrance jetties at the mouth of the Columbia River (MCR) (1885-1917) and the mouth of Grays Harbor (1898-1916) profoundly affected the evolution of the littoral cell. The change in boundary conditions at the estuary entrances enabled waves to rework the flanks of the ebb-tidal deltas onshore and supply enormous quantities of sand to the adjacent coasts (Kaminsky et al., 2010). Over several decades the initial sand pulses have 
been dispersed alongshore up to tens of kilometers from the estuary entrances. While here we

predominantly focus on the seasonal- to century scale evolution of the Long Beach and

Clatsop Plains sub-cells of the CRLC (Figures 2 and 3), which are located immediately north and south of the MCR, the changes along the Grayland Plains and North Beach sub-cells in many ways mirror the changes to the south (Kaminsky et al., 2010).

\section{Datasets and Methods}

The data collected and numerical models which have been applied to characterize and explain seasonal- to century-scale coastal evolution across multiple morphological units within the CRLC are briefly described below.

\subsection{Late Prehistoric Century-Scale Shoreline Change}

Geological investigations, ground penetrating radar (GPR), and cores were used to map the A.D. 1700 shoreline position throughout the CRLC, resulting from the last CSZ earthquakeinduced coastal subsidence and tsunami event (Woxell, 1998; Peterson et al., 1999; Peterson et al., 2010a). The position of the paleoscarp is the most landward and shallowest limit of a GPR reflector and is interpreted to correspond in position to the toe of a modern dune scarp.

A simple end-point 'pre-historic' shoreline change rate was computed between the GPRderived 1700 shoreline position and the first available National Ocean Service (NOS) T-sheet derived shoreline position ( 1880s) for the beaches north and south of the MCR. Due to a steep beach profile at the time of scarp formation, the 1700 shoreline position was assumed to be analogous to an average high water line shoreline proxy. Furthermore, the difference in shoreline proxy definition (paleoscarp versus subsequent shorelines derived from T-sheets) has relatively little effect on shoreline change rates derived over such long periods along beaches experiencing significant coastal progradation. Therefore, no horizontal adjustments were made to the two shoreline datasets prior to calculating end point shoreline change rates.

\subsection{Decadal- to Century-Scale Shoreline and Bathymetric Change}


Details on the methods used for computing decadal- to century-scale shoreline and bathymetric changes are given in Kaminsky et al. (1999), Kaminsky et al. (2010), and Ruggiero et al. (2013a) and therefore these methods are only briefly summarized here. Historical shoreline change rates were computed based on proxy-based shorelines (e.g., interpreted position of the average high water line) derived from NOS T-sheets and aerial photography (Kaminsky et al. 1999; Kaminsky et al., 2010), and datum-based shorelines (e.g. position of MHW) extracted from lidar data (Ruggiero et al., 2013a). The methods of Ruggiero et al., (2003), Moore et al. (2006), and Ruggiero and List (2009) were employed to correct for the proxy-datum bias associated with these differently derived shoreline positions. Historical linear regression and end-point shoreline change rates were calculated using the bias-corrected shoreline positions.

Bathymetric data come from the U.S. Coast and Geodetic Survey (USC\&GS), the National Ocean Service (NOS), the U.S. Army Corps of Engineers (USACE), the U.S. Geological Survey (USGS), and the Washington State Department of Ecology. Data from common eras were merged to form regional bathymetric surfaces as described in the regional sediment budget analysis of Buijsman et al. (2003a). Bathymetric-change surfaces were derived by subtracting the bathymetric surfaces of one era from another.

\subsection{Seasonal- to Decadal-Scale Nearshore, Beach, and Dune Morphology Monitoring}

Upper shoreface, nearshore, beach, and foredune evolution within the CRLC is being monitored with Real Time Kinematic Differential Global Positioning System (RTK DGPS) surveying techniques (Figures 1 and 4; Ruggiero et al., 2005; Stevens et al., 2012). To resolve the seasonal- to decadal-scale variability of the region's beaches and foredunes, topographic beach profiles are collected quarterly (ongoing since 1997) at locations nominally distributed in the alongshore at approximately $3 \mathrm{~km}$ (Figure 4C). Topographic beach profiles are measured by walking from the landward side of the primary foredune ridge, over the dune 
crest, to wading depth during spring low tides. Annually, a personal water craft (PWC)-based Coastal Profiling System (CPS) is used to measure nearshore morphology each summer at representative transects (Figure 4A) to depths seaward of measurable annual change ( -12 m MLLW; Ruggiero et al., 2005; Di Leonardo and Ruggiero, 2015). In situ beach measurements have been occasionally augmented by airborne lidar data (Figure 4B, Ruggiero et al., 2013a). We have developed automated methods to objectively and accurately extract important morphometrics from the various data sets (Mull and Ruggiero, 2014) to address questions regarding upper shoreface, sandbar, shoreline, and foredune evolution.

\subsection{Beach Grass Invasion Monitoring}

Dunes in the region were historically managed, since late in the $19^{\text {th }}$ century, to maximize dune stabilization through the planting of European beach grass, Ammophila arenaria. The switch in dominance from a native, Elymus mollis, to an exotic dune species resulted in a state change in coastal dune systems (Seabloom and Wiedemann, 1994). Prior to the invasion of the exotic species, the native dune plants formed small hillocks or short parallel ridges depending on sand supply. In contrast, Ammophila arenaria creates stable foredunes, with dune ridges reaching as much as $15 \mathrm{~m}$ tall which intercept sand and decrease sand supply to the back barrier. A second invader, Ammophila breviligulata (American beach grass) was introduced to the PNW in the middle of the $20^{\text {th }}$ century and is outcompeting European beach grass in southwest Washington and northwest Oregon (Hacker et al., 2012).

To document the colonization, spread, and dominance of the invasive beach grasses, plant community composition and Ammophila tiller density was measured in 1988, 2006, and 2009 within $20 \times 50 \mathrm{~cm}$ quadrats placed every $5 \mathrm{~m}$ along 33 foredune sites located throughout the CRLC (Figure 4E, Seabloom and Wiedemann, 1994; Hacker et al., 2012; Zarnetske et al., 2015). At each site, between 3 and 10 cross-shore transects were established where the relative abundance of the two non-native grasses (A. arenaria and A. breviligulata) and the 
native grass (E.Mollis) was measured at $10 \mathrm{~m}$ increments from approximately MHW to the lowest point on the back dune.

\subsection{Process Experiments}

Process-oriented field experiments were conducted off of Grays Harbor, WA, encompassing parts of both the Grayland Plains and North Beach sub-cells, in the fall of 1999 and the spring of 2001 (Figure 4D). While the fall 1999 experiment measured waves, currents, and suspended-sediment concentrations around an ebb-tidal delta in high-energy conditions, the spring 2001 field experiment was specifically designed to document hydrodynamic processes and nearshore morphological changes during the months when the beaches in the region typically begin to rebuild following episodic erosion during the winter. The experiment successfully measured bed sediment composition, point measurements of waves and currents, suspended sediment concentrations, and net bathymetric change. Both of these experiments provided valuable information for testing and improving numerical models of sediment transport and morphology change (Landerman et al., 2005; Ruggiero et al., 2009).

To characterize the dune-building capacity of the three beach grass species present in the CRLC, a moveable bed wind tunnel was constructed at the O. H. Hinsdale Wave Research Laboratory (HWRL), Corvallis, Oregon, USA, where a series of sand capture efficiency experiments were performed (Figure 4F, Zarnetske et al., 2012). Adult beach grass tillers with intact rhizomes were collected along the Oregon coast and planted in boxes filled with Oregon beach sand. Each of the three beach grass species were planted in three densities reflecting the range of tiller densities observed on coastal foredunes in the PNW. Two different wind conditions (low and high) were run on approximately 30 boxes at the HWRL and sand capture efficiency was assessed by simply dividing the mass of sediment trapped in each box by the mass provided to the box during each experimental run.

\subsection{Sediment Transport and Morphology Change Modeling}


342 A broad range of modeling approaches has been employed in the CRLC to improve knowledge and test hypotheses regarding coastal evolution. In particular, several modeling exercises were aimed at attempting to infer the relative contributions of alongshore versus cross-shore processes in seasonal- to decadal-scale morphological change. Below we briefly describe a subset of the modeling specifically focused on understanding progradational morphodynamics in the CRLC.

\subsubsection{Modeling Seasonal- to Interannual Scale Nearshore Profile Change}

A process-based morphological model, Delft3D (D3D; Lesser et al., 2004), was run in three modes (2DV, 2DH and 3D) to test three distinct hypotheses regarding the forcing responsible for observed seasonal-scale nearshore morphological changes during the spring 2001 Grays Harbor, WA experiment (Ruggiero et al., 2009). To test whether or not observed alongshore variability in onshore sandbar migration patterns was primarily due to the alongshore variability in initial bathymetry, a 2DV profile evolution model which accounts for crossshore processes but assumes alongshore uniformity of all physical processes was applied to two beach profiles located $2 \mathrm{~km}$ apart which exhibited significantly different morphological behavior. Morphological evolution was hindcast for a two-month period using measured wave heights, periods, and directions, as well as shore parallel currents as boundary conditions to the 2DV models, with the same environmental-forcing time series used to drive each of the models. To assess the influence of both alongshore variability in the initial bathymetry and alongshore variability in incident cross-shore hydrodynamic forcing, a 2DH D3D model was used to estimate alongshore varying wave and tidal forcing conditions which were then applied to the 2DV profile models. Finally, to test whether the observed spatial variability in profile change resulted from both alongshore and cross-shore gradients in sediment transport resulting from fully three-dimensional horizontal flow circulation(s), we modeled all relevant hydrodynamic and morphodynamic processes through the application of 
a fully three dimensional (3D) area model (Ruggiero et al., 2009). For all three model experiments, a sensitivity analysis was used to calibrate the cross-shore profile evolution model, optimize sediment transport model parameters (van Rijn, 2007), and tune the SWAN wave model (Booij et al., 1999).

In a separate study focused on interannual-scale sandbar variability along the Long Beach Peninsula, Cohn and Ruggiero (2016) used the deterministic 2DV profile model UNIBESTTC (WL|Delft Hydraulics, 1997). The model calculates cross-shore transport and changes in nearshore morphology, including accounting for wave propagation, mean currents, bottom orbital velocities, bed load and suspended load sediment transport, and bed level change.

\subsubsection{Modeling Annual- to Decadal-Scale Shoreline Change Modeling}

To test hypotheses explaining annual- to decadal-scale shoreline changes along the CRLC, Ruggiero et al. (2010b) employed the one-line shoreline change model UNIBEST-CL (WL|Delft Hydraulics, 1994). The model transformed modern day and projected future (Allan and Komar, 2000) wave climates from offshore to the shoreline, accounting for refraction, shoaling, and dissipation by wave breaking and bottom friction (Battjes and Stive, 1984). The cross-shore distribution of wave height, wave setup, and longshore currents were computed, accounting for both bottom friction and gradients in the radiation stress. Subsequently, the model calculated cross-shore distribution of longshore sediment transport using the total load sediment transport formula of Bijker (1971) and then solved the shoreline continuity equation on a staggered grid. As the shoreline prograded or retreated, the shoreline orientation changed and sediment transport rates adjusted to the updated local wave approach angle. However, as is typical with one-line shoreline models (e.g., Ashton et al., 2001), the cross-shore profiles retained a constant shape and simply translated horizontally as the shoreline changed.

\subsubsection{Modeling Annual- to Decadal-Scale Cross-shore Sediment Transport on the Lower} Shoreface 
To estimate sediment exchange between the lower and upper shoreface on annual- to decadalscales, here we apply the cross-shore sand transport model of Aagaard (2014). Cross-shore suspended transport is decomposed into contributions from mean and oscillatory terms representing contributions from currents (offshore directed) and waves (onshore directed, denoted with primes) respectively

$$
q_{x}=\left(\int_{z=0}^{z}\left(\left\langle u_{z}\right\rangle\left\langle c_{z}\right\rangle\right)+\left\langle u_{z}^{\prime} c_{z}^{\prime}\right\rangle d z\right)+\left(\langle c\rangle u_{r m s} \sin \beta\right)
$$

where $z$ is the vertical coordinate, $u_{z}$ is the cross-shore velocity, and $c_{z}$ is the suspended sediment concentration. The last term on the right hand side is a downslope, gravity-induced transport term where $\langle c\rangle$ is the depth-integrated total suspended-load transport and $\beta$ is the shoreface slope. Aagaard (2014) found that the time and depth-averaged sediment load, as well as the oscillatory sediment transport fluxes, were a function of the grain-related mobility number

$$
\psi=\frac{u_{s}^{2}}{(s-1) g D}
$$

where $u_{s}$ is the significant orbital velocity variance, $s$ is the relative sediment density, and $D$ is the mean grain size. The mean currents include undertow and Stokes drift and in combination are almost always directed offshore at the transition between the lower and upper shoreface, taken here to be approximately $-12 \mathrm{~m}$. In the application presented in this paper for the CRLC, the sediment transport model is applied using the Thornton and Guza (1983) random wave transformation model and standard approximations for depth-averaged undertow and Lagrangian mass transport (Aagaard, 2014).

\section{Results}

Between the 1700 tsunami paleoscarp and the pre-jetty shorelines of the 1870 s, the barriers north and south of the MCR prograded approximately $1.4 \mathrm{~m} / \mathrm{yr}$ (Table 1), with the highest 
rates of recovery (> $7 \mathrm{~m} / \mathrm{yr}$ ) associated with spit growth/recovery of the northern tip of the Long Beach Peninsula (Kaminsky et al., 2010). These beach progradation rates pre-date any significant human influence on CRLC shorelines and represent the influence of high rates of sediment supply from the Columbia River (Gelfenbaum et al., 1999), gradients in longshore sediment transport, and, most likely, net onshore sediment fluxes from the lower shoreface. The construction of jetties at the mouth of the Columbia River (1885-1917) and Grays Harbor (1898-1916) altered the local sediment supply to beaches in the CRLC by establishing new boundary conditions and inducing system-wide morphological responses at annual-to-century time scales (Buijsman et al., 2003a; Buijsman et al., 2003b). Kaminsky et al. (2010) describe the historical evolution of the CRLC in significant detail and the interested reader is referred there. To summarize the historical evolution since the late $1800 \mathrm{~s}$, the CRLC has experienced: a) large signals of shoreline change (Table 1, on horizontal scales of meters to kilometers); b) large signals of bathymetric change (on vertical scales of centimeters to meters, Figure 5); and c) large fluxes of sand (typically $10^{1}$ to $10^{2} \mathrm{~m}^{3} / \mathrm{yr}$ per meter alongshore). In the following sections, we describe the changes observed over seasonal- to century-scales within the CRLC in multiple morphological units. The sections are ordered such that we describe sediment transport processes and morphodynamics from offshore to onshore, i.e., from the shoreface, through the nearshore, to the beach, and ultimately to the foredunes.

\subsection{Shoreface}

Regional decadal- to century-scale morphological changes primarily attributed to construction of the Columbia River jetties, were calculated from merged regional bathymetric surfaces (Figure 5, Buijsman et al., 2003a). While some of the most extraordinary changes occur at the MCR (see Kaminsky et al., 2010 for details), we focus here on (annualized) changes offshore of the barrier beaches. 

and 1926, Clatsop Spit (Compartment CPdn, Figure 5a) gained over $7 \mathrm{~km}^{2}$ of land, accumulating $0.5 \mathrm{Mm}^{3} / \mathrm{yr}$. Just to the south of this area, the Clatsop Plains mid- to lower shoreface (Compartments 8 and 9, Figure 5a) between -25 and -10m NAVD 88 eroded by a total of $0.5 \mathrm{Mm}^{3} / \mathrm{yr}$, nearly balancing the observed accumulation of the Clatsop Plains upper shoreface (-10 m to $0 \mathrm{~m}$, Compartments 10 and 11, Figure 5a). On the north side of the MCR, Benson Beach (Compartment LBds), a pocket beach between the MCR North Jetty and North Head (Figure 3B), gained nearly $4 \mathrm{~km}^{2}$ of land, accumulating $0.4 \mathrm{Mm}^{3} / \mathrm{yr}$. North of North Head, the shoreface had spatially fluctuating patterns of erosion and accretion while the Long Beach Peninsula accumulated $0.5 \mathrm{Mm}^{3} / \mathrm{yr}$ of sand during this period.

Between 1926 and 1958, the shoreface offshore of the northern portion of Clatsop Plains, from approximately -55 to -23 m NAVD 88 (Compartment 22, Figure 5b), fluctuated with up to a few meters of erosion and accumulation. The mid- to lower shoreface, between approximately -23 and -10 m NAVD 88 (Compartments 11, 12, 13, and 14, Figure 5b), reveals significant erosion of $2.3 \mathrm{Mm}^{3} / \mathrm{yr}$. Nearly $60 \%$ of this erosion occurred across the former southern flank of the ebb shoal of the MCR which by this time had become separated from the inlet due to the construction of the Columbia River South Jetty. Immediately onshore of this erosion zone in the former ebb shoal, the upper shoreface (Compartments 9 and 10) and Clatsop Spit (Compartment 8) also eroded by a total of $0.4 \mathrm{Mm}^{3} / \mathrm{yr}$. However, further to the south, the upper shoreface (Compartments 19, 20, and 21) accreted $0.5 \mathrm{Mm}^{3} / \mathrm{yr}$. These erosion and accretion patterns suggest, but do not conclusively prove, a net onshore sediment flux as the upper shoreface accretion accounts for about half of the erosion that occurred directly offshore on the mid- to lower shoreface. Clatsop Plains experienced a net accumulation of $61.2 \mathrm{Mm}^{3}\left(1.9 \mathrm{Mm}^{3} / \mathrm{yr}\right)$ during this period with increasing rates towards the south. Nearly all bathymetric areas north of the MCR experienced net accumulation during 
this same time period. From approximately -23 to $-10-m$ NAVD 88 depth is a moderate accretion band (Compartment 16) that accumulated $0.4 \mathrm{Mm}^{3} / \mathrm{yr}$. Extending northward and onshore from the outer delta is a nearshore corridor (Compartment 3) of moderate accumulation $\left(0.3 \mathrm{Mm}^{3} / \mathrm{yr}\right)$ that connects to the upper shoreface. From the North Jetty to about $15 \mathrm{~km}$ northward, the upper shoreface (Compartments 2, 18, and 17) accumulated 1.6 $\mathrm{Mm}^{3} / \mathrm{yr}$. These bathymetric change patterns suggest onshore and northward net sediment flux pathways as the MCR ebb-tidal delta continued to deflate decades following jetty construction.

Between 1958 and 1999 the Clatsop Plains mid- to lower shoreface (Compartment 14) eroded $0.6 \mathrm{Mm}^{3} / \mathrm{yr}$. Clatsop Plains accumulated $1.2 \mathrm{Mm}^{3} / \mathrm{yr}$, including $0.5 \mathrm{Mm}^{3} / \mathrm{yr}$ on the upper shoreface (Compartments 12, 17, 18, and 19). The southern Long Beach shoreface (Compartments 8, 9, 15, and 16) shallower than -23 m NAVD 88 accumulated $1.7 \mathrm{Mm}^{3} / \mathrm{yr}$. Over the total length of the Long Beach Peninsula, the upper shoreface and barrier accumulated a total of $3.1 \mathrm{Mm}^{3} / \mathrm{yr}$.

The bathymetric change analyses reveal shoreface profiles across much of the inner shelf north and south of the MCR that have significantly adjusted over time scales of decades, with the upper shoreface having aggraded on the order of a couple of meters (Figure 6). Offshore of Long Beach and portions of the Clatsop Plains sub-cell, the toe of the progradational sand wedge has migrated seaward on the order of a few hundred meters. In the northernmost Clatsop Plains, the progradational sand wedge has remained relatively stationary in association with shoreface rotation (Figure 6b). In contrast, the southern Long Beach mid- to lower shoreface (Figure 6a) has aggraded in response to an abundant supply of sand eroded from the northern Clatsop Plains shoreface and dispersed northward from the Columbia River ebb-tidal delta. Beach profiles extending from the shoreface to the foredune, collected annually since 
1998, reveal progradation of the beach and foredunes yet relatively minor morphological change in water depths deeper than $9 \mathrm{~m}$ on interannual to decadal time-scales (Figure 7). Ove $\mathrm{r} 16$ years of measurements there is only approximately $20-30 \mathrm{~cm}$ of aggradation in water dep ths of $\sim-10$ to $-12 \mathrm{~m}$ (Figure 7), a signal that is only just above the vertical resolution of the $\mathrm{m}$ easurements (Ruggiero et al., 2005). Kaminsky et al. (2010) showed that the upper shoreface along the Long Beach Peninsula aggraded approximately $2.5 \mathrm{~m}$ from 1926 to 2000. While the decadal-scale shoreface accretion estimates of $\sim 3.3 \mathrm{~cm} / \mathrm{yr}$ (from Kaminsky et al., 2010) agree relatively well with the modern annual average rates of accretion $(\sim 1.0-2.0 \mathrm{~cm} / \mathrm{yr})$ measured using the CPS, the relatively slow rates of morphological change shown in Figure 7 confirms why direct evidence for net shoreface feeding remains elusive.

\subsection{Nearshore Sandbar Zone}

The nearshore bar zone, extending almost $1.5 \mathrm{~km}$ from the shoreline (taken here to be $\sim 3.0 \mathrm{~m}$ contour NAVD88) is characterized by significant spatial and temporal variability (Figures 7 and 8) with morphological features (subtidal sandbars) that can at times contain significantly more volume of sediment than the sand dunes backing the beaches (Figure 7). The CRLC nearshore typically exhibits between 1 and 3 distinct subtidal sandbars and between 0 and 2 distinct intertidal sandbars, ranging in height from approximately $0.2 \mathrm{~m}$ (measurement limit) to a remarkable $6.0 \mathrm{~m}$ as measured from the seaward crest to landward trough (Di Leonardo and Ruggiero, 2015). Sandbar crest positions vary from approximately $100 \mathrm{~m}$ from the shoreline for intertidal bars to well over $1,000 \mathrm{~m}$ from the shoreline for outer subtidal bars (Figure 7).

On seasonal scales, significant onshore sandbar migration can occur during fair weather conditions. The 2001 field experiment, along the beaches adjacent to Grays Harbor captured the transition between the high-energy erosive conditions of winter and the lowenergy beach-building conditions typical of summer (Ruggiero et al., 2009). Over the course 
of approximately four months, the experiment documented shoreline progradation on the order of 10-20 m, on average approximately $70 \mathrm{~m}$ of onshore sandbar migration, and approximately $80,000 \mathrm{~m}^{3} / \mathrm{m}$ of sediment accumulation above the $8.0 \mathrm{~m}$ contour (Figure 8 ).

During this time period significant alongshore variability was observed in the seasonal morphological response of the sandbar over a 4-km reach of coast with sandbar movement ranging from $20 \mathrm{~m}$ of offshore migration to over $175 \mathrm{~m}$ of onshore bar migration. Both the observations and D3D model results suggest that alongshore variations in the initial bathymetry were primarily responsible for the observed alongshore variable morphological changes due to a positive feedback between sediment transport and the bar position and bar crest elevation (Ruggiero et al., 2009).

While during calm conditions subtidal sandbars typically migrate onshore, at interannual scale sandbars observed along the Long Beach Peninsula appear to follow the pattern of net offshore bar migration (NOM) that has been observed along several other coasts around the world (e.g., Ruessink and Kroon, 1994; Plant et al., 1999; Shand et al., 1999, Shand and Bailey, 1999, Walstra et al., 2012; Walstra et al., 2016). Interannual NOM has been shown to follow a three-stage process; bar generation near the shoreline, seaward migration, and bar decay in the outer nearshore. Outer bar decay is typically associated with the onset of offshore migration of the next landward bar. With only annual surveys of nearshore morphology it typically takes several years of measurements to identify the patterns and full life cycles of individual bars. Between 1998 and 2013 we have tracked portions of the life cycles of at least seven individual sandbars using alongshore averaged beach and nearshore profiles between km 143 and 142 (Figures 4 and 9, Cohn et al., 2016). Annual surveys suggest 6 occasions in which the outer bar decayed during this time (Figure 9). The interpretation of NOM in the CRLC, as in other locations (e.g., Ruessink et al., 2003, Walstra et al., 2012) does not necessarily imply net offshore sediment transport, but simply an 
540 offshore migration and decay of the morphological features. In fact, Wijnberg (1995) provides a strong argument for the possibility of net onshore sediment transport occurring simultaneously with offshore bar migration. Based on a detailed sediment balance Wijnberg (1995) concludes that the process of bar degeneration is associated with onshore directed transport, that the offshore movement of the bar that is located landward of the degenerating outer bar is at least partially caused by the net onshore directed transport, and that when sediment is removed from the outer bar it is immediately entrained into the inner bar system and subsequently redistributed from there.

\subsection{Shoreline}

The beaches of the CRLC are still evolving from anthropogenic perturbations to the natural system, the largest of which (jetty construction) occurred over a century ago (Kaminsky et al., 2010). The majority of the beaches in the CRLC responded to these impacts over the last century with rates of beach progradation significantly higher than late prehistoric rates (Table 1, Figure 10). The initial shoreline response due to construction of the Columbia River North Jetty was rapid, although local shoreline change was initially confined to the development of a pocket beach between the jetty and North Head. Not until after 1926 (over ten years after jetty construction) did the shoreline north of North Head show significant changes (Kaminsky et al., 2010). From the 1870s to 2002, the average (long-term) shoreline change rate along Long Beach was $2.6 \mathrm{~m} / \mathrm{yr}$ (Table 1), with variability in local shoreline change rates ranging from -12.1 to $10.3 \mathrm{~m} / \mathrm{yr}$ (Ruggiero et al., 2013). The average shoreline progradational trend was even higher during the late historic period (1980s - 2002, short-term), with a rate of $4.7 \mathrm{~m} / \mathrm{yr}$ (Figure 10, Table 1). Change rate variability was also higher during this more recent period than over the long-term, ranging from -18.7 to 23.2 $\mathrm{m} / \mathrm{yr}$. Only three percent of the Long Beach Peninsula coast was eroding during this period. 

sediment budget of Buijsman et al. (2003a), Ruggiero et al. (2010) were able to successfully hindcast the multi-decadal shoreline evolution of the Long Beach Peninsula over the latter part of the $20^{\text {th }}$ century (1955 to 1995$)$. Sediment supply from the deflating ebb tidal delta

$\left(\sim 2.3 \mathrm{Mm}^{3} / \mathrm{yr}\right.$, Figure 5c) and from the Columbia River as well as onshore-directed sediment feeding from the lower shoreface $\left(\sim 0.4 \mathrm{Mm}^{3} / \mathrm{yr}\right)$ were critical for balancing the barrier beach sediment budget over this time period and therefore essential to making sensible shoreline change hindcasts. The mean modeled shoreline advance over the 40 -year period was $168 \mathrm{~m}$ over $35 \mathrm{~km}$ of the peninsula (RMS error $=11 \mathrm{~m}$ ) successfully reproducing the approximately $90 \mathrm{Mm}^{3}$ of sediment that accumulated on the upper shoreface and barrier of Long Beach Peninsula.

At century-scale (1870s-2002), the average shoreline change rate along the Clatsop Plains was $3.1 \mathrm{~m} / \mathrm{yr}$ (Figure 10), by far the highest rate of littoral cell averaged coastal change during this period not only in the CRLC but in all of Oregon and Washington (Ruggiero et al., 2013a). The highest Oregon statewide long-term progradation rate, $15.5 \mathrm{~m} / \mathrm{yr}$ at one particular cross-shore transect, also occurs in this cell. Only 10 percent of the Clatsop Plains shoreline was eroding between the 1870s and 2002. At decadal-scale (1967-2002), the rates of progradation were slower, averaging $1.9 \mathrm{~m} / \mathrm{yr}$, with only 2 percent of the coastline eroding. Averaged over the beach profiles collected along the Long Beach Peninsula, the shoreline (3.0 m NAVD88) change rate between 1997 and 2014 was 3.7 m/yr (Table 1, Figures 7 and 11). This rate is approximately triple that of the 'natural' late prehistoric rate of $1.3 \mathrm{~m} / \mathrm{yr}(1700-1880 \mathrm{~s}$, Table 1$)$ and is almost a full century after the construction of the Columbia River North Jetty, the anthropogenic influence primarily responsible for the increased rates of shoreline change. These more recent shoreline change rates, however, do indicate a potential slowing of shoreline progradation along the southern 10 to $15 \mathrm{~km}$ of Long 
Beach Peninsula between the late historical period (1980s-2002) and the modern interannualto decadal- period (1997-2014), perhaps an indication that the coast is nearing a dynamic equilibrium with the reduced sediment supply. South of the Columbia River, the modern interannual shoreline change rate along the Clatsop Plains (derived from beach profiles) demonstrated continued slowing of the rate of progradation with an average shoreline advance of $1.1 \mathrm{~m} / \mathrm{yr}$ (Figure 12).

Trends and variability of various elevation contours are evident from the quarterly beach profiles collected between 1997 and 2014 (Figure 11 and 12). Elevations higher on the beach profile are significantly less variable than lower elevation contours, as they are less (often) affected by high-frequency water level oscillations. For example, the standard deviation of MLLW (approximately $0 \mathrm{~m}$ NAVD88, not shown) is about $30 \mathrm{~m}$ while the standard deviation of the 5.0-m contour (approximately the toe of the dune) is about $3 \mathrm{~m}$. Similar results have been found for the majority of the beach profiles collected within the CRLC (Ruggiero et al., 2003). It is apparent from these data that coastal change measured from a proxy or datum-intercept along the upper beach profile can provide a more reliable measure of net change than a lower elevation or more seaward shoreline proxy that is subject to higher frequency and larger magnitude fluctuations (Figures 11 and 12).

While the quarterly beach profiles of the CRLC beach monitoring program precludes detailed measurements of intertidal bar welding at regional scale, a process that requires more frequent observations to fully resolve (Cohn et al., 2015), some site specific data has captured portions of the process. Intertidal bar migration from the lower intertidal, up the beachface, and the eventual welding with the upper beachface is illustrated in Figure 13 with data collected in 2011 at Cape Disappointment State Park, the pocket beach just north of the Columbia River North Jetty (Stevens et al., 2012). During the low to moderate wave conditions of spring and summer, sediment is entrained on the stoss slope and deposited on 
the lee side during swash uprush events, resulting in a slow landward migration of these features (Anthony et al. 2004; Anthony et al. 2006; Masselink and Russell, 2006; Wijnberg and Kroon, 2002). Rates of migration computed here to be approximately $1.5 \mathrm{~m} /$ day compare well to observed rates in other locations (ranging from $\sim 1-10 \mathrm{~m} /$ day). Intertidal bar migration rates have been shown to be likely, but not conclusively, related to a number of factors including tide level, wave energy, and grain size (Houser et al., 2006). When environmental conditions are conducive, these features eventually completely weld to the shoreline whereupon they become no longer distinguishable from the surrounding landform (red line in Figure 13, Masselink et al., 2006). The process of intertidal sandbar welding (Figure 13) most likely supplies a substantial volume of sediment from the nearshore to the beach via a predominantly cross-shore process (e.g., Cartier and Hequette, 2013).

The frequency of welding events is highly site specific, in part due to the local environmental conditions and also as a function of sediment availability. In some locations intertidal bars initially formed as storm deposits may migrate back onshore over the course of multiple years (Aagaard et al., 2004; Houser et al., 2015). In other settings these bar features form in-situ within the inner surf zone or at the base of the swash zone prior to migrating onshore. In locations where there is substantial sediment availability there may be numerous welding events within a single year (Cohn et al., 2015). In the case that a bar welds, the shoreline will prograde, widening the cross-shore fetch length and increasing the potential flux of aeolian sediment transport (de Vries et al., 2014). However, synchronous with the welding event, there must also be suitable environmental conditions (sufficient wind, low water levels, limited moisture) to allow for sediment to subsequently blow into the back beach and dunes (Houser, 2009). Together, the processes of intertidal bar formation, onshore migration, and welding to the shoreline represent a (seasonally) periodic, and potentially significant quantity of sand being transferred from the nearshore to the dry beach - 
potentially critical for building both beaches and dunes (Houser, 2009).

\subsection{Foredunes}

Most of the region's beaches and foredunes were eroded/scarped during the two intense winters of 1997/1998 (a major El Niño event, e.g., Kaminsky et al., 1998) and 1998/1999 (a moderate La Niña event, Ruggiero et al., 2005) that featured higher than normal wave heights and water levels (Allan and Komar, 2002). Subsequent to these winters, the beaches and foredunes have, for the most part, experienced significant seaward progradation and vertical accretion, resuming the long-term historical trend (Figures 11 and 12). The interannual- to decadal-scale foredune evolution during this recovery period (1999 to 2014) has exhibited interesting alongshore variable behavior. Between one to two new foredunes formed along the Long Beach Peninsula, with as much as five meters of vertical aggradation. For example, Figure 11 shows the summer 1997 beach profile backed by a dune reaching just over $9 \mathrm{~m}$ (NAVD88) in elevation and a small fronting incipient foredune. By summer 2000 this new foredune feature had increased in elevation by about $1.5 \mathrm{~m}$ and in subsequent years accreted significantly. By summer 2005 its crest elevation was approximately $9 \mathrm{~m}$, approximately the same elevation as the 1997 foredune crest, but almost $50 \mathrm{~m}$ seaward of its position. A second 'new' foredune feature started to form around 2004/2005 (Figure 11). By summer 2012 this third feature in the sequence of foredune ridges had also achieved a crest elevation of about $9 \mathrm{~m}$. The cross-shore position of this third dune was only about $25 \mathrm{~m}$ seaward of the $2^{\text {nd }}$ dune in the series. The bottom panel of Figure 11 illustrates the cross-shore varying rate of vertical aggradation along the profile. At the location of the 2014 foredune crest the aggradation rate was approximately $0.4 \mathrm{~m} / \mathrm{yr}$.

In contrast to the new foredune ridge development that occurred along the Long Beach Peninsula (Figure 11), the foredunes along the Clatsop Plains (Figure 12) simply increased in height and volume due to a steady sediment supply but beach progradation rates 
significantly slower than those to the north (about half). While the vertical growth rate in some locations is higher at the Clatsop Plains profile than the Long Beach Peninsula profile, the dune form here is increasing in height and migrating seaward at approximately the same rate as the shoreline.

At sub-cell scale, foredune geomorphology differs significantly on either side of the MCR (Mull and Ruggiero, 2014, Figure 14). As extracted from 2002 lidar data, the dunes north of the MCR (Long Beach Peninsula) are relatively low in elevation (mean dune crest elevation is $8.1 \mathrm{~m}, \mathrm{STD}=0.7 \mathrm{~m}$ ), while the dunes on the south side (Clatsop Plains) are much taller (mean dune crest elevation is $13.0 \mathrm{~m}, \mathrm{STD}=2.5 \mathrm{~m}$ ). The elevation of the dune toe is much more consistent across the MCR averaging $5.5 \mathrm{~m}$ in Long Beach $(\mathrm{STD}=0.6 \mathrm{~m})$ and $5.1 \mathrm{~m}$ in the Clatsop Plains $(\mathrm{STD}=0.6 \mathrm{~m})$.

Recent advances in PNW foredune ecomorphodynamics based on field observations a nd moveable bed wind tunnel experiments (e.g., Hacker et al., 2012; Zarnetske et al., 2012; Z arnetske et al., 2015), have demonstrated that a species-specific biophysical feedback occurs between sand deposition, growth habit, and growth-habit-mediated sand capture efficiency, re sulting in distinctly different dune geomorphologies in locations dominated by different grass species. The dense, vertical growth habit of A. arenaria allows it to capture more sand, produ ce more vertical tillers, and build taller, narrower dunes, while the less dense, lateral growth $\mathrm{h}$ abit of A. breviligulata is more suited for building shorter but wider dunes. The relatively sho rt foredunes along the Long Beach Peninsula (Figure 14) are dominated by A. breviligulata ( Seabloom and Wiedemann, 1994; Hacker et al., 2012) while the higher foredunes along the Clatsop Plains have approximately even distributions of A. breviligulata and A. arenaria ( Hacker et al., 2012).

Physical processes also play a major role in the evolution of the CRLC foredunes (e.g., Zarnetske et al., 2015). Psuty's (1986) conceptual beach-dune interaction model assumes that 
sediment supply, both to the beach and to the dune, is the driving factor for foredune evolution. When sediment supply to the beach is large (as is the case along the Long Beach Peninsula), foredune development is limited by the rapid beach progradation when the development of new, seaward foredunes limit the supply of sediment to the existing foredune and lead to a series of low foredune ridges. When sediment supply is lower, (e.g., Clatsop Plains over recent decades) lower rates of shoreline progradation allow for the development of a single, larger foredune. The species-specific feedbacks described above (e.g., Zarnetske et al., 2012) coupled with the sediment supply model of Psuty (1986) are required to explain the variability in dune morphology along the CRLC (e.g., Hesp, 1984; Ruggiero et al., in revision).

\section{Discussion and Conclusions}

In our discussion below we first speculate on the relative role of cross-shore and alongshore processes responsible for the observed sediment accumulation at a particular location within the CRLC through the use of a simple meso-scale sediment budget based on observations and morphological change models. We next emphasize the importance of sediment supply and quantitative knowledge of sediment flux pathways in interpreting seasonal- to century-scale coastal evolution. Finally, we synthesize our knowledge of the morphodynamics of prograding beaches within the CRLC over a range of time scales.

\subsection{Meso-Scale Sediment Budget}

Subsequent to the intense ENSO dominated winters of 1997/98 and 1998/99, the beaches along the Long Beach Peninsula exhibited net residual sand accumulation resulting in significant shoreline advance of approximately 4 m/yr. During the period 1999-2011 two new foredunes formed with the backshore accumulating sand at rates of over $10 \mathrm{~m}^{3} / \mathrm{m} / \mathrm{yr}$ (Figure 11). Gradients in alongshore sediment transport (Ruggiero et al., 2010), net onshore-directed cross-shore sediment transport within the surf zone, and cross-shore feeding from a shoreface 
out of equilibrium with forcing conditions (Kaminsky et al., 2010) are hypothesized to each be partially responsible for the sediment supplied to the beaches and dunes during this study period. Below we develop a simple meso-scale sediment budget using the data described above and three simple sediment transport/morphological change models (Ruggiero et al., 2013b) to test this hypothesis.

The observed sediment accumulation, $\Delta V$, along a 3-km reach of the Long Beach Peninsula between 1999 and 2011 (Figure 15), is taken to be a combination of gradients in longshore sediment transport $\left(Q_{i n}-Q_{o u t}\right)$ and onshore sediment feeding from the shoreface, $q_{o n}$, via

$$
\Delta V=\left(Q_{\text {in }}-Q_{\text {out }}\right) \Delta t \pm q \Delta x \Delta t
$$

Alternating erosion and deposition parallel to the shoreline in the bathymetric difference plot is due to the migration of sand bars (Figure 15). During this period a total of approximately $100 \mathrm{~m}^{3} / \mathrm{m} / \mathrm{yr}$, or $300,000 \mathrm{~m}^{3} / \mathrm{yr}$ within the focus area, accumulated between $12 \mathrm{~m}$ (seaward limit of data) and $+9 \mathrm{~m}$ (initial foredune crest elevation). Ten percent of this material was stored in the foredunes representing a cross-shore sediment flux, $q_{\text {dune }}$, from the beach to the backshore (Figure 15).

The same one-line shoreline change model runs applied to simulate historical shoreline change as described in Ruggiero et al. (2010b) was used here to compute the gradients in longshore sediment transport across the 3-km study area. The model runs suggest that on average $~ 70 \mathrm{~m}^{3} / \mathrm{m} / \mathrm{yr}$ of sediment accumulates in the nearshore 'active zone', shallower than $\sim-12 \mathrm{~m}$, from longshore transport gradients $\left(Q_{i n}-Q_{o u t}\right.$, Figure 15). Note that as mentioned above, the model simulations required a cross-shore feeding boundary condition, estimated based on the system sediment budget work of Buijsman et al. (2003a), of approximately $10 \mathrm{~m}^{3} / \mathrm{m} / \mathrm{yr}, q_{o n_{-1}}$ (Figure 15 ), from the shoreface (deeper than $-12 \mathrm{~m}$ ) for accurate hindcasts. 
To quantify the relative contribution of cross-shore processes to the overall

morphological changes that occurred between 1999 and 2011 we have also used the deterministic cross-shore sediment transport model UNIBEST-TC (WL|Delft Hydraulics, 1997). Computations of annual cross-shore morphological change from the simulations (Cohn and Ruggiero, 2016) indicate that approximately $9 \mathrm{~m}^{3} / \mathrm{m} / \mathrm{yr}$ enters the control volume of our study from deeper than $-15 \mathrm{~m}\left(q_{\text {on__}_{2}}\right)$. The model predicts a net positive exchange of sediment from the shoreface to the beach while simultaneously predicting the characteristic NOM cycle observed in the CRLC (not shown).

Finally, we use the cross-shore sediment transport model of Aagaard (2014) as an independent check on the above results (Equations 1 and 2). A 32-year hindcast of offshore wave height and period (WIS station 83013, $24 \mathrm{~m}$ water depth) is shoaled across a beach profile approximating that of the Oysterville, WA area. As in the application given by Aagaard (2014), net annual $q_{\text {on_3 } 3}$ is a small residual (positive) difference between onshoredirected transport due to oscillatory motions and offshore-directed transport due to mean currents. At -12 m water depth, net annual cross-shore transport varies between approximately 10 and $15 \mathrm{~m}^{3} / \mathrm{m} / \mathrm{yr}$, averaging $12.8 \mathrm{~m}^{3} / \mathrm{m} / \mathrm{yr}$. It is confirming that the Aagaard (2014) model and the UNIBEST-TC simulations result in similar estimates of net onshoredirected transport from the lower to upper shoreface that are required to balance the mesoscale sediment budget on the Long Beach Peninsula.

In summary, the model applications suggest that about $70 \%$ of the accumulated volume is from gradients in longshore processes while modeled onshore-directed cross-shore sediment transport can account for only between $10-15 \%$ of the total accumulation. The accumulation along the Long Beach Peninsula therefore appears to be dominated by longshore processes at decadal- to century-scale. However, at event- to interannual-scale, Ruggiero et al. (2010) hypothesized that cross-shore processes may dominate. 
765 Approximately $15-20 \%$ of the sediment that accumulated along this stretch of the Long

Beach Peninsula remains unaccounted for in this simple sediment budget, possibly a result of observational and model uncertainty. One unexplored sediment source is longshore gradients in windblown sand transport, a subject of ongoing investigations.

\subsection{Shoreface Sand Supply to Barriers}

The possibility of net sand supply from the lower shoreface to the upper shoreface, and eventually through the nearshore to the beach and foredunes has been hypothesized to occur in a wide variety of coastal environments (e.g., Stive et al., 1999; Cowell et al., 2001; Kaminsky and Ferland, 2003; Aagaard et al., 2004). Cowell et al. (2001) summarize several convergent lines of evidence including long-term bathymetric change analysis, in-situ measurements of sediment transport on the shoreface, and modeling (both behavior and process-based) of shoreface sediment transport that all indicate that sand supply from the shoreface is more widespread than commonly believed. From a process-based perspective it has been hypothesized that during energetic conditions, such as the waning stages of storms when the downwelling associated with wind forcing abates, wave asymmetry induced sediment transport is primarily onshore directed (Stive et al., 1999). Aagaard et al. (2004) suggest a possible mechanism for shoreface sediment transport through the surf zone to the intertidal where sand then becomes available for dune/barrier building. They hypothesize that a combination of relatively large fluxes of onshore transport due to asymmetric incident waves and relatively small undertow velocities (occurring on low sloping beaches during surges) at times of high energy results in persistent onshore transport.

Several lines of evidence specific to the CRLC, many of which have been described here, suggest that the shoreface has been a significant source of onshore directed sediment. The detailed littoral cell-scale sediment budget analyses performed in Kaminsky et al. (2001) and Buijsman et al. (2003a) demonstrate that only part of the large rate of barrier 
progradation along the Long Beach Peninsula during the historical period can be accounted for through direct sand supply from the Columbia River and through the degeneration of the ebb-tidal delta. Further, the upper shoreface accumulation along Clatsop Plains, particularly between 1926 and 1958 (Figure 5), is also at least in part due to onshore transport of sand that has eroded from the mid- to lower shoreface (between roughly 10 and 30-m water depth). Finally, as described above, Ruggiero et al. (2010b) were only able to successfully hindcast decadal scale shoreline change patterns in the region after the addition of an onshore feeding (from the shoreface) boundary condition.

\subsection{Synthesis of Seasonal- to Decadal-Scale Coastal Progradation}

Detailed observations over the last $\sim$ two decades allows us to speculate on the dominate processes responsible for the prograding barriers in the CRLC (Figure 16). At seasonal scale, low-energy asymmetric waves allow for significant onshore migration of subtidal bars. Under these low-energy conditions sediment accumulated in the inner surf zone by both cross-shore and alongshore processes is transported onshore via the welding of intertidal bars. Intertidal bars migrate up the beach and weld to the backshore, prograding the beach, increasing the aeolian sediment transport fetch, and likely providing a sediment flux to form incipient foredunes or feed existing foredunes. On interannual- to decadal-scales, the subtidal sandbars in the CRLC most likely follow the net offshore migration cycle, even while net cross-shore transport is most likely directed landward and the barriers are prograding rapidly. Gradients in longshore transport dominate decadal-scale coastal evolution, delivering large quantities of sand to the nearshore. Subsequent large sediment fluxes to the beaches and dunes, and a species-specific feedback between invasive beach grasses and dune morphology result in either multiple prograding dune ridges (e.g., Long Beach Peninsula) or high aggrading single dune ridges (Clatsop Plains). At decadal-scale, onshore feeding from the lower shoreface is estimated to be on the order of $10^{1} \mathrm{~m}^{3} / \mathrm{m} / \mathrm{yr}$, rates significantly higher than observed in other 
locations (Cowell et al., 2001).

In light of projections of as much or more than one meter of sea-level rise by the end of the $21^{\text {st }}$ century (IPCC, 2014), a systems-based view is essential for predicting the effect of climate change along barrier beaches. In the CRLC, sediment supply from the MCR ebb-tidal delta flanks and lower shoreface has largely masked the decline in Columbia River sediment supply resulting from flow regulation and dredging disposal practices. It is unknown how long this situation will be maintained, particularly under sea-level rise scenarios for the remainder of the century. Reliable predictions of coastal response to sea-level rise depend on understanding sediment flux pathways, system sediment budgets, and the morphodynamics of prograding beaches at multiple scales.

\section{Acknowledgements}

The authors gratefully acknowledge the support of the U.S. Geological Survey and the Washington State Department of Ecology as part of the Southwest Washington Coastal Erosion Study. Thanks also to NANOOS (Northwest Association of Networked Ocean Observing Systems) and the U.S. Army Corps of Engineers (Portland District) for supporting additional observations reported on here. Ruggiero was supported by the National Oceanic and Atmospheric Administration (NOAA award NA15OAR4310243) while writing this manuscript.

\section{References}

Aagaard, T., 2014. Sediment supply to beaches: Cross-shore sand transport on the lower shoreface, Journal of Geophysical Research Earth Surface, 119, 913-926, doi:10.1002/ 2013JF003041.

Aagaard, T., Davidson-Arnott, R., Greenwood, B., Nielsen, J., 2004. Sediment supply from shoreface to dunes: linking sediment transport measurements and long-term morphological evolution, Geomorphology, 60, 205-224. 
Aagaard, T., Hughes, M.G., Baldock, T.E., Greenwood, B., Kroon, A., Power, H.E., 2012. Sediment transport processes and morphodynamics on a reflective beach under storm and non-storm conditions, Marine Geology, 326-328, 154-165.

Allan, J.C., Komar, P.D., 2000. Are ocean wave heights increasing in the eastern North Pacific? EOS, Transactions of the American Geophysical Union 47, 561-567.

Allan, J.C., Komar, P.D., 2002. Extreme storms in the Pacific Northwest coast during the 1997-98 El Niño and 1998-99 La Niña. Journal of Coastal Research, 18(1), 175-193.

Allan, J.C. Komar, P.D.,. 2006. Climate controls on U.S. West Coast erosion processes. Journal of Coastal Research, 22, 511-529.

Anthony, E. J., Levoy, F., \& Monfort, O. (2004). Morphodynamics of intertidal bars on a megatidal beach, Merlimont, Northern France. Marine Geology, 208(1), 73-100.

Anthony, E., Venhee, S., Ruz, M. (2006). Short-term beach-dune sand budgets on the North Sea coast of France: Sand supply from shoreface to dunes, and the role of wind and fetch. Geomorphology: 81, 316-329.

Ashton, A., Murray, A.B., Arnoult, O., 2001. Formation of coastline features by large-scale instabilities induced by high-angle waves. Nature, 414, 296-300.

Atwater, B.F., 1996. Coastal evidence for great earthquakes in western Washington. In: Rogers, A.M., Walsh, T.J., Kockelman, W.J., Priest, G.R. (Eds.), Assessing Earthquake Hazards and Reducing Risk in the Pacific Northwest: U.S. Geological Survey Professional Paper 1560, vol. 1, pp. 77-90.

Barbier, E., Hacker, S.D., Kennedy, C., Koch, E., Stier, A.D., Silliman, B., 2011. The value of estuarine and coastal ecosystem services. Ecological Monographs 81:169-193.

Battjes, J.A., Stive, M.J.F., 1984. Calibration and verification of a dissipation model for random breaking waves. Proceeding of 19th Conference on Coastal Engineering. ASCE, pp. 649-660. 
Bauer, B., Davidson-Arnott, R. (2002). A general framework for modeling sediment supply to coastal dunes including wind angle, beach geometry, and fetch effects. Geomorphology, 49, 89-108.

Bijker, E.W., 1971. Longshore transport computations. Journal of Waterways, Harbors and Coastal Engineering Division, ASCE 97, 687-701.

Booij, N., Ris, R.C., Holthuijsen, L.H., 1999. A third-generation wave model for coastal regions, 1, model description and validation. Journal of Geophysical Research 104 (C4), 7649-7666.

Buijsman, M.C., Sherwood, C.R., Gibbs, A.E., Gelfenbaum, G., Kaminsky, G.M., Ruggiero, P., and Franklin, J. 2003a. Regional sediment budget of the Columbia River littoral cell, USA: Analysis of bathymetric- and topographic-volume change, U.S. Geological Survey Open File Report, 02-281.

Buijsman, M. C., Kaminsky, G. M., Gelfenbaum, G., 2003b. Shoreline change associated with jetty construction, deterioration, and rehabilitation at Grays Harbor, Washington. Shore and Beach, 71, 15-22.

Cartier, A. and Hequette, A., 2013. The influence of intertidal bar-trough morphology on sediment transport on macrotidal beaches, northern France, Zeitschrift fur Geomorphologie, 57,3, 325-347, DOI:10.1127/0372-8854/2013/0105.

Cohn, N. and Ruggiero, P., 2016. The influence of seasonal to interannual nearshore morphological variability on extreme water levels: Modeling wave runup on dissipative beaches, Coastal Engineering,

Cohn, N., Ruggiero, P., Ortiz, J., Walstra, D.J., 2014. Investigating the role of complex sandbar morphology on nearshore hydrodynamics. In: Green, A.N. and Cooper, J.A.G. (eds.), Proceedings $13^{\text {th }}$ International Coastal Symposium (Durban, South Africa), Journal of Coastal Research, Special Issue No. 70, pp. 053-058, ISSN 0749-0208. 
Cohn, N., Anderson, D., Ruggiero, P., 2015. Observations of intertidal bar welding along a high energy, dissipative coastline. Proceedings of the Coastal Sediments Conference ' 15

Cooper, W. S. 1958. Coastal sand dunes of Oregon and Washington. - Memoir 72. Geological Society of America

Cowell, P.J., Roy, P.S., Jones, R.A., 1995. Simulation of large scale coastal change using a morphological behavior model, Marine Geology 126, 46-61.

Cowell, P.J., Stive, M.J.F., Roy, P.S, Kaminsky, G.M., Buijsman, M.C., Thom, B.G., Wright, L.D, 2001. Shoreface sand supply to beaches. Proceedings $27^{\text {th }}$ International Coastal Engineering Conference, 2495-2508.

Cowell, P.J., Stive, M.J.F., Niedoroda, A.W., de Vriend, H.J., Swift, D.J.P., Kaminsky, G.M., Capobianco, M., 2003a. The coastal-tract (Part 1): a conceptual approach to aggregated modeling of low-order coastal change. Journal of Coastal Research 19 (4), 812-827.

Cowell, P.J., Stive, M.J.F., Niedoroda, A.W., Swift, D.J.P., de Vriend, H.J., Buijsman, M.C., Nicholls, R.J., Roy, P.S., Kaminsky, G.M., Cleveringa, J., Reed, C.W., de Boer, P.L., 2003b. The coastal-tract (Part 2): applications of aggregated modeling to lower order coastal change. Journal of Coastal Research 19 (4), 828-848.

Davidson-Arnott, R. (1988). Temporal and spatial controls on beach/dune interaction, Long Point, Lake Erie. Journal of Coastal Research, 3, 131-136.

de Vriend, H.J., 1998. Large-scale coastal morphological predictions: a matter of upscaling? Proceedings of the 3rd International Conference on Hydroscience and Engineering, Cottbus/Berlin.

de Vries, S., van Thiel de Vries, J., van Rijn, L., Arens, S., Ranasinghe, R., 2014. Aeolian sediment transport in supply limited situations. Aeolian Research, 12, 75-85.

Di Leonardo, D., Ruggiero, P., 2015. Regional scale sandbar variability: Observations from the U.S. Pacific Northwest, Continental Shelf Research, 95,74-88, 
http://dx.doi.org/10.1016/j.csr.2014.12.012i

Doyle, D., 1996. Beach response to subsidence following a Cascadia subduction zone earthquake along the Washington-Oregon coast: M. S. Thesis, Portland State University, Portland, Oregon, 113 pp.

Duran, O.,Moore, L., 2013. Vegetation controls on the maximum size of coastal dunes, PNAS, doi/10.1073/pnas.1307580110.

Fuhrman, D.R., Schloer, S., Sterner, J., 2013. RANS-based simulation of turbulent wave boundary layer and sheet-flow sediment transport processes, Coastal Engineering, 73, 151-166.

Gelfenbaum, G., Sherwood, C. R., Peterson, C. D., Kaminsky, G., Buijsman, M., Twichell, D., Ruggiero, P., Gibbs, A., Reed, C., 1999. The Columbia River Littoral Cell: A Sediment Budget Overview, Proc. of Coastal Sediments ‘99, ASCE, 1660-1675.

Gelfenbaum, G., Kaminsky, G.M., 2010. Large-scale coastal change in the Columbia River littoral cell: An overview. Marine Geology 273, 1-10.

Guerry, A.D., MH Ruckelshaus, K Arkema, JR Bernhardt, G Guannel, CK Kim, M Marsik, M Papenfus, JE Toft, G Verutes, SA Wood, M Beck, F Chan, KMA Chan, G Gelfenbaum, BD Gold, BS Halpern, WB Labiosa, SE Lester, PS Levin, M McField, ML Pinsky, M Plummer, S Polasky, P Ruggiero, DA Sutherland, H Tallis, A Day, J Spencer, 2012. Modeling benefits from nature; using ecosystem services to inform coastal and marine spatial planning. International Journal of Biodiversity Science, Ecosystem Services \& Management, DOI:10.1080/21513732.2011.647835

Gutierrez, J. L. et al. 2012. Physical ecosystem engineers and the functioning of estuaries and coasts. - In: Heip, C. H. R. et al.(eds), Vol. 7. Functioning of estuaries and coastal ecosystems. - In: Wolanski, E. and McLusky, D. (series eds.), The treatise on estuarine and coastal science, Elsevier. 
Hacker, S., Zarnetske, P., Seabloom, E., Ruggiero, P., Mull, J., Gerrity, S., Jones, C., 2012. Subtle differences in two non-native congeneric beach grasses significantly affect their colonization, spread, and impact, Oikos, doi: 10.1111/j.1600-0706.2011.01887.x

Hapke, C.J., Reid, D., Richmond, B.M., Ruggiero, P., List, J., 2006. National assessment of shoreline change: Part 3: Historical shoreline changes and associated coastal land loss along the sandy shorelines of the California coast: U. S. Geological Survey Open-file Report 2006-1219.

Hapke, C.J.; Lentz, E.E.; Gayes, P.T.; McCoy, C.A.; Hehre, R.; Schwab, W.C., Williams, S.J., 2010. A review of sediment budget imbalances along Fire Island, New York: can nearshore change explain the deficit? Journal of Coastal Research . 26(3), 510-522.

Hesp, P. A., 1984, Foredune Formation in Southeast Australia, Academic Press Australia.

Hesp, P.A., 2002. Foredunes and blowouts: initiation, geomorphology and dynamics. Geomorphology 48, 245-268.

Hoefel, F., Elgar, S., 2003. Wave-induced sediment transport and sandbar migration. Science, $299,1885$.

Houser, C., 2009. Synchronization of transport and supply in beach-dune interaction. Progress in Physical Geography, 33: 6, 733-746.

Houser, C., Ellis, J. (2013) Beach and Dune Interaction. In: John F. Shroder (ed.) Treatise on Geomorphology, Volume 10, pp. 267-288. San Diego: Academic Press.

Houser, C., Greenwood, B., 2003. Response of a swash bar to a sequence of storm events. Proceedings of the Coastal Sediments Conference, 1-13.

Houser, C., Greenwood, B., Aagaard, T. (2006). Divergent response of an intertidal swash bar. Earth Surface Processes and Landforms, 31, 1775-1791.

Houser, C., Wernette, P., Rentschlar, E., Jones, H., Hammond, B., Trimble, S. (2015). Poststorm beach and dune recovery: Implications for barrier island resilience. 
IPCC, 2014. Climate Change 2014: Impacts, Adaptation and Vulnerability: Contributions of Working Group II to the Fifth Assessment Report of the Intergovernmental Panel on Climate Change, Cambridge Univ. Press, New York.

Kaminsky, G.M., Ruggiero, P., Gelfenbaum, G., 1998. Monitoring coastal change in southwest Washington and northwest Oregon during the 1997/98 El Niño, Shore and Beach, 66(3), 42-51.

Kaminsky, G.M., Daniels, R.C., Huxford, R., McCandless, D., Ruggiero, P., 1999. Mapping erosion hazard areas in Pacific County, Washington, Journal of Coastal Research, Special Issue \#28, 158-170.

Kaminsky, G.M., Buijsman, M.C., Ruggiero, P., 2001. Predicting shoreline change at decadal scale in the Pacific Northwest, USA. Proceedings of the International Conference on Coastal Engineering, ASCE, 2000.

Kaminsky, G.M., Ferland, M.A., 2003. Assessing the connections between the inner shelf and the evolution of Pacific Northwest barriers through vibracoring. International Conference on Coastal Sediments, ASCE.

Kaminsky, G.M., Ruggiero, P., Buijsman, M.C., McCandless, D., Gelfenbaum, G., 2010. Historical evolution of the Columbia River littoral cell, Marine Geology, DOI:10.1016/j.margeo.2010.02.006.

Kana, T.W., Rosati, J.D., Traynum, S.B., 2011. Lack of evidence for onshore sediment transport from deep water at decadal time scales: Fire Island, New York. In: Roberts, T., Rosati, J., and Wang, P. (eds.), Proceedings, Symposium to Honor Dr. Nicholas Kraus, Journal of Coastal Research, Special Issue 59, pp. 61-75. 
Komar, P.D., Allan, J.C., Ruggiero, P., 2011. Sea level variations along the US Pacific Northwest coast: tectonic and climate controls, Journal of Coastal Research (27) 5, 808823, DOI:10.2112/JCOASTRES-D-10-00116.1.

Kranenburg, W.M., Ribberinjk, J.S.. Schretlen, J.J.L.M.,. Uittenbogaard, R.E., 2013. Sand transport beneath waves: The role of progressive wave streaming and other free surface effects, Journal of Geophysical Research Earth Surface, 118, 122-139, doi:10.1029/2012JF002427.

Kroon A., 1994. Sediment transport and morphodynamics of the beach and nearshore zone near Egmond, the Netherlands . PhD thesis, Faculteit Ruimtelijke Wetenschappen Universiteit Utrecht.

Landerman, L., Sherwood, C.R., Gelfenbaum, G., Lacy, J., Ruggiero, P., Wilson, D., Chisholm, T., Kurrus, K., 2004. Grays Harbor Sediment Transport Experiment Spring 2001 — Data Report. Data Series 98: US Geological Survey Data Series.

Lesser, G., Roelvink, J.A., vanKester, J.A.T.M., Stelling, G.S., 2004. Development and validation of a three-dimensional morphological model. Coastal Engineering 51, 883915.

Masselink, G., Knott, A., Davidson-Arnott, R., 2006. Morphodynamics of intertidal bars in wave dominated coastal settings - A review. Geomorphology, 73, 33-49.

Masselink, G., Russell, P., 2006. Flow velocities, sediment transport and morphological change in the swash zone of two contrasting beaches. Marine Geology, 227, 227-240.

Moore, L.J., Ruggiero, P., List, J.H., 2006. Comparing mean high water and high water line shorelines: Should proxy-datum offsets be incorporated in shoreline change analysis? Journal of Coastal Research, 22(4), 894-905.

Mull, J., Ruggiero, P., 2014. Estimating storm-induced dune erosion and overtopping along 
1015

1016

1017

1018

1019

1020

1021

1022

1023

1024

1025

1026

1027

1028

1029

1030

1031

1032

1033

1034

1035

1036

1037

1038

1039

U.S. West Coast beaches, Journal of Coastal Research, 30(6), 1173-1187, DOI:

\subsection{2/JCOASTRES-D-13-00178.1.NRC, 2012}

Murray, A.B., Coco, G., Goldstein, E.B., 2014. Cause and effect in geomorphic systems: Complex systems perspectives, Geomorphology 214, 1-9.

National Research Council, 2012. Sea level rise for the Coasts of California, Oregon, and Washington: past, present, and future. The National Academies Press.

Peterson, C.D., Gelfenbaum, G., Jol, H.M., Phipps, J.B., Reckendorf, F., Twichell, D.C., Vanderburgh, S., Woxell, L., 1999. Great earthquakes, abundant sand, and high wave energy in the Columbia cell, USA. Proceedings of Coastal Sediments '99, pp.1676-1691.I

Peterson, C.D., Doyle, D.L., Barnett, E.T., 2000. Coastal flooding and beach retreat from coseismic subsidence in the central Cascadia margin, USA. Environmental \& Engineering Geoscience VI (3), 255-269.

Peterson, C.D., Vanderburgh, S., Roberts, M.C., Jol, H.M., Phipps, J., Twichell, D.C., 2010a. Composition, age, and depositional rates of shoreface deposits under barriers and beach plains of the Columbia River littoral cell, USA, Marine Geology, doi:10.1016/j.margeo.2010.02.003.

Peterson, C.D., Jol, H.M., Vanderburgh, S., Phipps, J., Percy, D., Gelfenbaum, G., $2010 b$. Dating of late Holocene shoreline positions by regional correlation of coseismic retreat events in the Columbia River littoral cell, Marine Geology, doi:10.1016/j.margeo.2010.02.004.

Plant, N.G., Holman, R.A., Freilich, M.H., 1999. A simple model for interannual sandbar behavior, Journal of Geophysical Research, 104(C7), 15,755-15,776.

Psuty, N.P. 1986. A dune/beach interaction model and dune management. Thalassas 4:11-15.

Riggs, S.R., Ames, D.V., 2003. Drowning the North Carolina Coast: Sea-level rise and estuarine dynamics, North Carolina Sea Grant Publication, 152pp. 
1040

1041

1042

1043

1044

1045

1046

1047

1048

1049

1050

1051

1052

1053

1054

1055

1056

1057

1058

1059

1060

1061

1062

1063

1064

Roelvink, D., Reniers, A., van Dongeren, A., van Thiel de Vries, J., McCall, R., Lescinksi, J., 2009. Modelling storm impacts on beaches, dunes, and barrier islands. Coastal Engineering, 1133-1152.

Ruessink, B.G., Kroon, A., 1994. The behaviour of a multiple bar system in the nearshore zone of Terschelling, the Netherlands: 1965:1993. Marine Geology, 121, 187-197.

Ruessink, B.G., Wijnberg, K.M., Holman, R.A., Kuriyama, Y., Van Enckevort, I.M.J., 2003. Intersite comparison of interannual nearshore bar behavior. J. Geophys. Res. Ocean 108.

Ruggiero, P., Kaminsky, G.M., Gelfenbaum, G., 2003. Linking proxy-based and datumbased shorelines on high-energy coastlines: Implications for shoreline change analyses, Journal of Coastal Research, SI-38, 57-82.

Ruggiero, P., Kaminsky, G.M., Gelfenbaum, G., Voigt, B., 2005. Seasonal to interannual morphodynamics along a high-energy dissipative littoral cell, Journal of Coastal Research, 21(3), 553-578.

Ruggiero, P., List, J.H., 2009. Improving Accuracy and Statistical Reliability of Shoreline Position and Change Rate Estimates, Journal of Coastal Research, 25(5), 1069-1081.

Ruggiero, P., Walstra, D.J., Gelfenbaum, G., Ormont, M.V., 2009. Seasonal scale nearshore morphological evolution: Field observations and modeling, Coastal Engineering, (56) 1153-1172, DOI:10.1016/j.coastaleng.2009.09.003.

Ruggiero, P., Komar, P.D., Allan, J.C., 2010a. Increasing wave heights and extreme-value projections: the wave climate of the U.S. Pacific Northwest, Coastal Engineering, 57, 539-552, doi:10.1016/j.coastaleng.2009.12.005.

Ruggiero, P., Buijsman, M., Kaminsky, G.M., Gelfenbaum, G., 2010b. Modeling the effects of wave climate and sediment supply variability on large-scale shoreline change, Marine Geology, 273, 127-140, DOI:10.1016/j.margeo.2010.02.008.

Ruggiero, P., Kratzmann, M.A., Himmelstoss, E.G., Reid, D., Allan, J., Kaminsky, G., 2013a, 
National assessment of shoreline change: Historical shoreline change along the Pacific Northwest Coast: U.S. Geological Survey Open-File Report 2012-1007, 62 p.

Ruggiero, P., Kaminsky, G.M., Hacker, S., 2013b, Morphodynamics of Prograding Beaches, Proceedings of Coastal Dynamics 2013, ASCE, Bordeaux, France.

Ruggiero, P., Hacker, S., Seabloom, E., Zarnetske, P., in revision. The role of vegetation in determining dune morphology, exposure to sea level rise, and storm-induced coastal hazards: A U.S. Pacific Northwest perspective, in Barrier dynamics and the impact of climate change on barrier evolution, Moore and Murray Eds., Springer.

Sallenger A.H., 2000. Storm impact scale for barrier islands. J. Coast. Res. 16 (3), 890-895.

Schwab, W.C., Thieler, E.R., Allen, J.R., Foster, D.S., Swift, B.A., Denny, J.F., 2000a. Influence of inner-continental shelf geologic framework on the evolution and behavior of the barrier-island system between Fire Island Inlet and Shinnecock Inlet, Long Island, New York. Journal of Coastal Research, 16(2), 408-422.

Schwab, W.C., Baldwin, W.E., Hapke, C.J., Lentz, E.E., Gayes, P.T., Denny, J.F., List, J.H., Warner, J.C., 2013, Geologic evidence for onshore sediment transport from the innercontinental shelf-Fire Island, New York: Journal of Coastal Research, v. 29, no. 3, p. 526-544, doi:10.2112/JCOASTRES-D-12-00160.1.

Seabloom, E.W. , Wiedemann, A.M. 1994. Distribution and effects of Ammophila breviligulata Fern. (American beachgrass) on the foredunes of the Washington coast. Journal of Coastal Research 10: $178-188$.

Seabloom, E. W., P. Ruggiero, S. D. Hacker, J. Mull, and P. Zarnetske. 2013. Invasive grasses, climate change, and exposure to storm-wave overtopping in coastal dune ecosystems. Global Change Biology 19:824-832.

Shand, R.D., Bailey, D.G., 1999. A review of net offshore bar migration with photographic illustrations from Wanganui, New Zealand, Journal of Coastal Research 15, 365-378. 
Shand, R.D., Bailey, D.G., Shepard, M.J., 1999. An inter-site comparison of net offshore bar migration characteristics and environmental conditions, Journal of Coastal Research, 15(3), 750-765.

Stevens, A.W., Gelfenbaum, G., Ruggiero, P., Kaminsky, G.M, 2012. Southwest Washington littoral drift restoration—Beach and nearshore morphological monitoring: US Geological Survey Open-File Report 2012-1175, 67 p.

Stive, M.J.F., Cloin, B., Jimenez, J., Bosboom, J., 1999. Long-term cross-shoreface sediment fluxes, Proceedings Coastal Sediments '99, 505-518.

Stive, M.J.F., DeVriend, H.J.,1995. Modelling shoreface profile evolution, Marine Geology, $126,235-248$.

Thornton, E., Humiston, R., Birkemeir, W., 1996. Bar-trough generation on a natural beach. Journal of Geophysical Research 101, 12097-12110.

Thornton, E.B., Guza, R.T., 1983. Transformation of wave height distribution, J. Geophys. Res., 88, 5925-5938.

Van Rijn, L.C., 2007. Unified view of sediment transport by currents and waves. I: initiation of motion, bed roughness, and bed-load transport. Journal of Hydraulic Engineering, ASCE 133 (6), 649-667. doi:10.1061/(ASCE)0733-9429(2007)133:6 (649) June 2007.

Walstra, D.J.R., Reniers, A.J.H.M., Ranasinghe, R., Roelvink, J.A., Ruessink, B.G., (2012). On bar growth and decay during interannual net offshore migration. Coast. Eng. 60, 190-200.

Walstra, D.J.R., Wesselman, D.A., van der Deijl, E.C., Ruessink, G., (2016). On the intersite variability in inter-annual nearshore sandbar cycles, Journal of Marine Science and Engineering, 4, 15, doi:10.3390/jmse4010015.

Wijnberg, K., (1995). Morphologic behavior of a barred coast over a period of decades, Utrecht: Koninklijk Nederlands Aardrijkskundig Genootschap; Utrecht: Faculteit 
Wijnberg, K., Kroon, A. (2002). Barred beaches. Geomorphology, 48, 103-110.

WL|Delft Hydraulics, 1994. UNIBEST, A software suite for the simulation of sediment transport processes and related morphodynamics of beach profiles and coastline evolution, Programme manual. WL|Delft Hydraulics, Delft, The Netherlands, pp. 39.

WL|Delft Hydraulics, 1997, UNIBEST-TC 2.0, Overview of model formulations, Delft Hydraulics H2305.42.

Woxell, L.K., 1998. Prehistoric beach accretion rates and long-term response to sediment depletion in the Columbia River littoral system, USA, MS Thesis, Portland State 


\section{Table Captions}

Table 1. Littoral cell averaged shoreline change rates (and ranges) along two of the four subcells of the CRLC.

\section{Figure Captions}

Figure 1. Conceptual diagram indicating morphological units and time and space scales of variability across the coastal planform. (Modified from Ruggiero et al., 2005).

Figure 2. Map of the Columbia River littoral cell (inset shows location within the U.S. Pacific Northwest) as separated into four sub-cells by the Columbia River, Willapa Bay, and Grays Harbor estuaries. The tan colors (on the outer coast) indicate relatively low lying accreted barrier plains.

Figure 3. Oblique aerial images of the four sub-cells of the Columbia River littoral cell. A) Clatsop Plains, OR , B) Long Beach Peninsula, WA, C) Grayland Plains, WA, and D) North Beach, WA. (Photo Credit: Tor Clausen)

Figure 4. Middle panel. Location of quarterly topographic beach profiles (Clatsop Plains and Long Beach Peninsula sub-cells only are shown) that resolve beach and foredune evolution (green circles), the locations of annual nearshore bathymetric surveys (red lines), and the locations of dune grass surveys (blue circles). The photographs surrounding the middle panel represent the various approaches used to investigate and monitor the morphodynamics of prograding beaches including A) PWC-based nearshore bathymetric surveys, B) air-based lidar, C) cross-shore topographic beach profiles, D) instrumented tripods for hydrodynamic and sediment transport measurements during process experiments, E) quadrats for beach and 
dune ecology surveys, and F) moveable bed wind tunnel aeolian sediment transport studies.

Figure 5. Mouth of the Columbia River and adjacent coast bathymetric change between a) 1868 and 1926, b) 1926 and 1958, and c) 1958 and 1999. Circled numbers refer to compartments described in the text. Letters A, B, E, and F in c) refer to dredged material disposal sites. (After Kaminsky et al., 2010)

Figure 6. Conceptual diagrams of decadal-scale shoreface and barrier evolution north and south of the MCR. The Long Beach Peninsula experienced shoreface translations during much of the $20^{\text {th }}$ century while portions of the Clatsop Plains experienced shoreface rotation.

Figure 7. Example evolution of beach profile from km 143 (Profile 60, northern most profile in Figure 4) along the Long Beach Peninsula. Origin is the approximate shoreline position ( 3.0 m contour) from the 1998 survey.

Figure 8. Measured beach profile and associated volume changes between 6 May 2001 and 6 August 2001 at North Beach, WA. Profiles are alongshore averaged over 1-km (6 profiles spaced at 200m in the alongshore). (From Ruggiero et al. 2009).

Figure 9. Top panel) Position of mean bar crests and Bottom panel) mean bar crest depths from 1998 to 2013 averaged over approximately $1 \mathrm{~km}$ in the alongshore between profile 63 to 69 (km 143 - km 142 in Figure 4) along the Long Beach Peninsula. Colors represent individual sandbars. (modified from Cohn et al., 2016).

Figure 10. Graphs showing long- (left panel, 1800s - 2002) and short-term (middle panel, 
1967/80s - 2002) shoreline change rates (black lines on plots) for the Columbia River littoral cell. Shaded gray area behind long- and short-term rates represents uncertainty associated with rate calculation. (After Ruggiero et al., 2013)

Figure 11. Profile (top left panel) and contour (top right panel) change rates (CCR) between 1997 and 2014 at km 143 in the Long Beach Peninsula (see Figure 4 for location). The bottom left panel shows annual-averaged vertical change rates (VCR) at all alongshore positions. The bottom right panel shows time series of vertical accretion at three locations. The red text in the upper right hand panel indicates the long-term (LT, 1870s-2002) and shortterm (ST, 1980s-2002) shoreline change rates at this location (from Figure 10).

Figure 12. Profile (top left panel) and contour (top right panel) change rates (CCR) between 1997 and 2014 at km 92 in the Clatsop Plains (see Figure 4 for location). The bottom left panel shows annual-averaged vertical change rates (VCR) at all alongshore positions. The bottom right panel shows time series of vertical accretion at three locations. The red text in the upper right hand panel indicates the long-term (LT, 1870s-2002) and short-term (ST, 1967-2002) shoreline change rates at this location (from Figure 10).

Figure 13. Example topographic profile in Cape Disappointment State Park (immediately north of the Columbia River North Jetty) during spring and summer 2001 demonstrating onshore migration of intertidal bars.

Figure 14. Dune toe and dune crest elevations along the Long Beach and Clatsop Plains subcells of the CRLC. 
1212 Figure 15. Left Panel) Location of quarterly topographic beach profiles (along the Long

1213 Beach Peninsula) that resolve beach and foredune evolution (magenta circles), the locations

1214 of annual nearshore bathymetric surveys (yellow lines), and the locations of dune grass

1215 surveys (blue circles). Right panel) Sediment budget for an $\sim 3 \mathrm{~km}$ portion of the Long Beach

1216 Peninsula (location indicated on left panel) computed between 1999 and 2011. Red arrows

1217 and text represent longshore sediment fluxes, blue arrows and text represent cross-shore

1218 sediment fluxes from the shoreface, and green arrows and text represent cross-shore sediment

1219 fluxes from the beach to the dunes. Three different approaches for estimating onshore feeding

1220 from the lower shoreface, $\mathrm{q}_{\mathrm{on} \_1}, \mathrm{q}_{\mathrm{on} \_} 2$, and $\mathrm{q}_{\mathrm{on} \_}$, , result in similar magnitude sediment fluxes.

Figure 16. Conceptual model of seasonal- through interannual- through decadal-scale morphodynamics based on observations from the Columbia River littoral cell. 
Figure 1

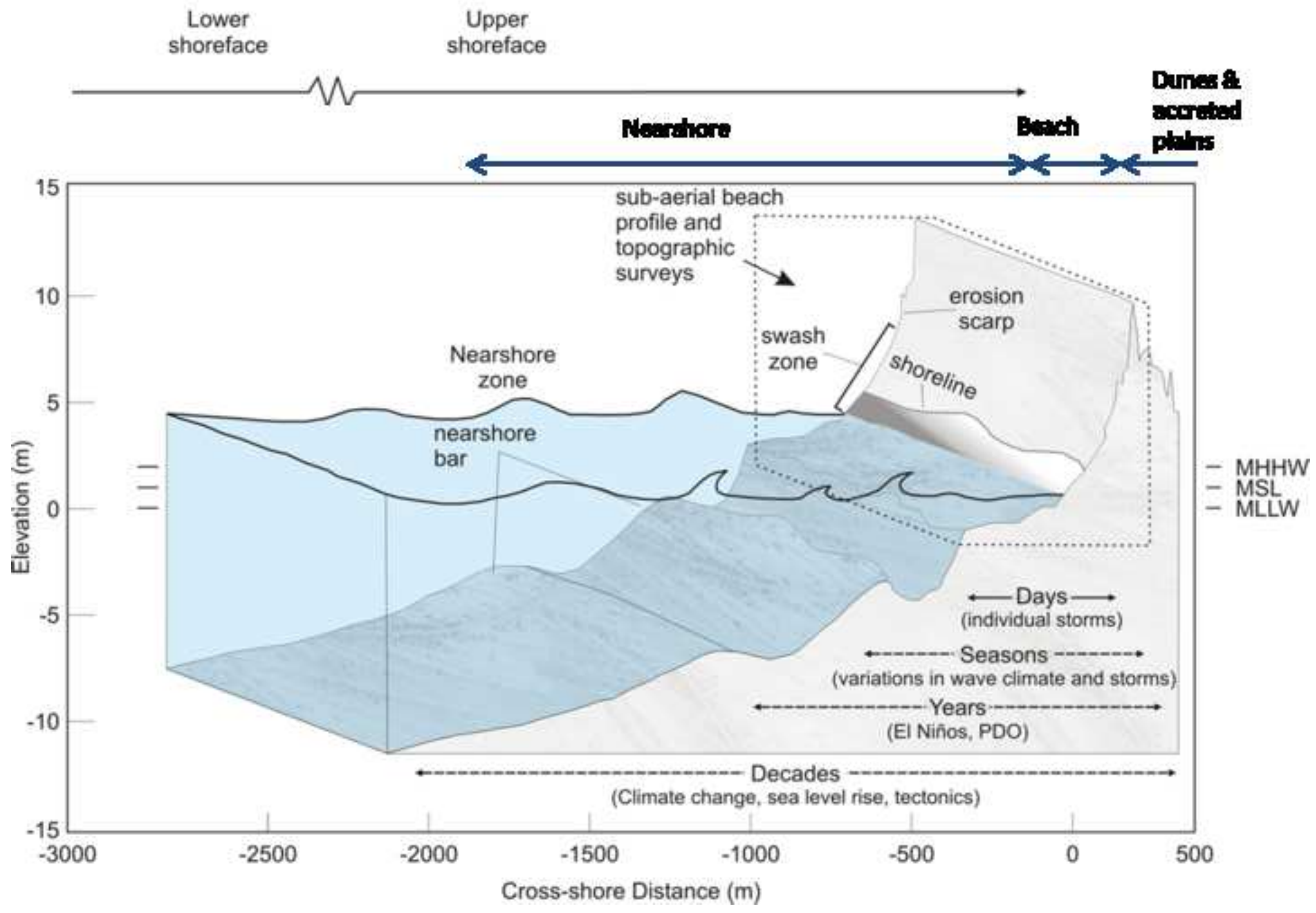




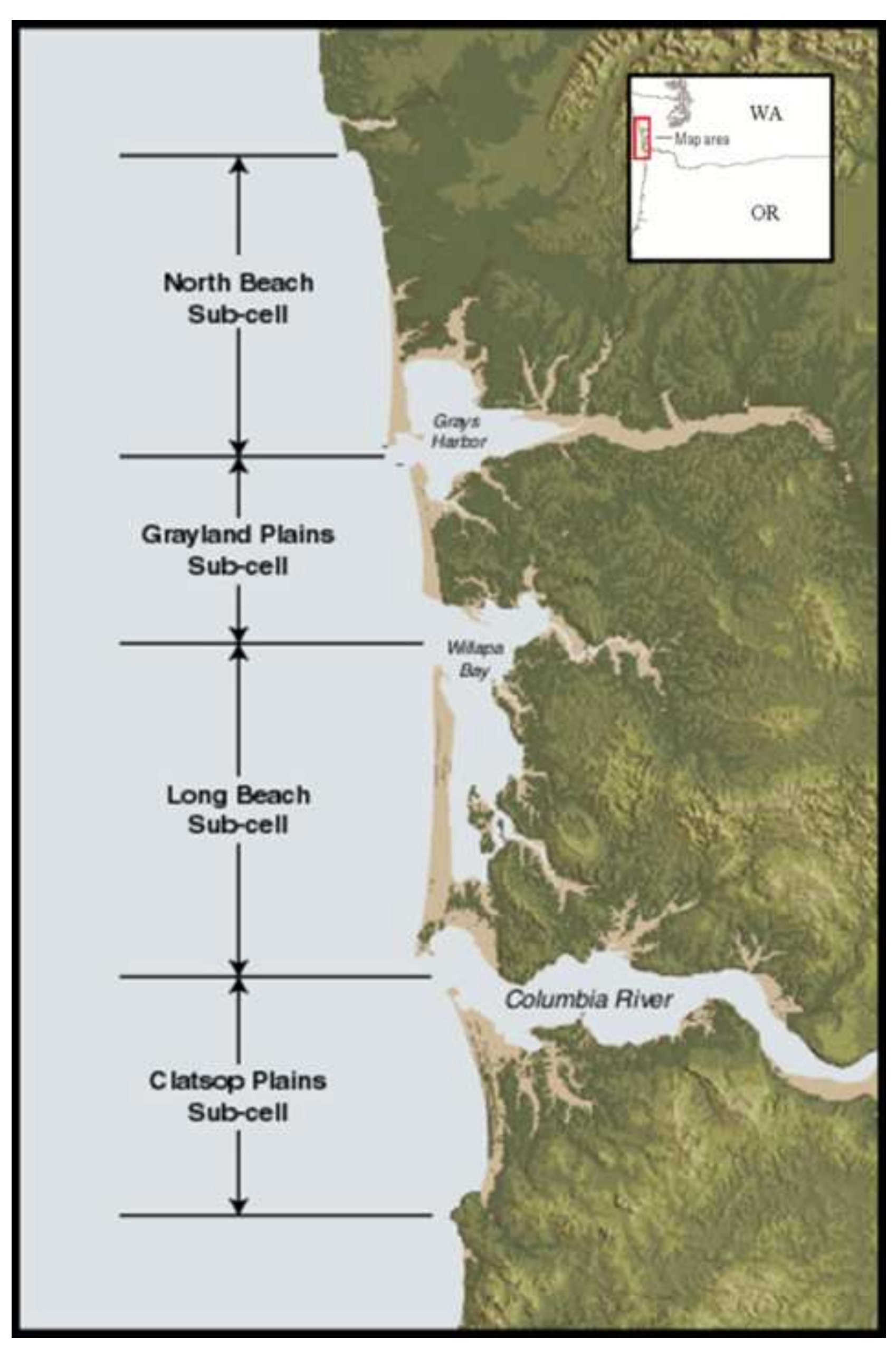

Figure 2
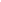

Fing

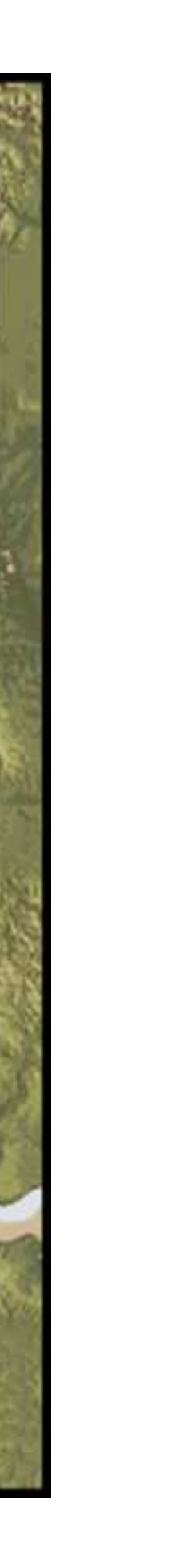




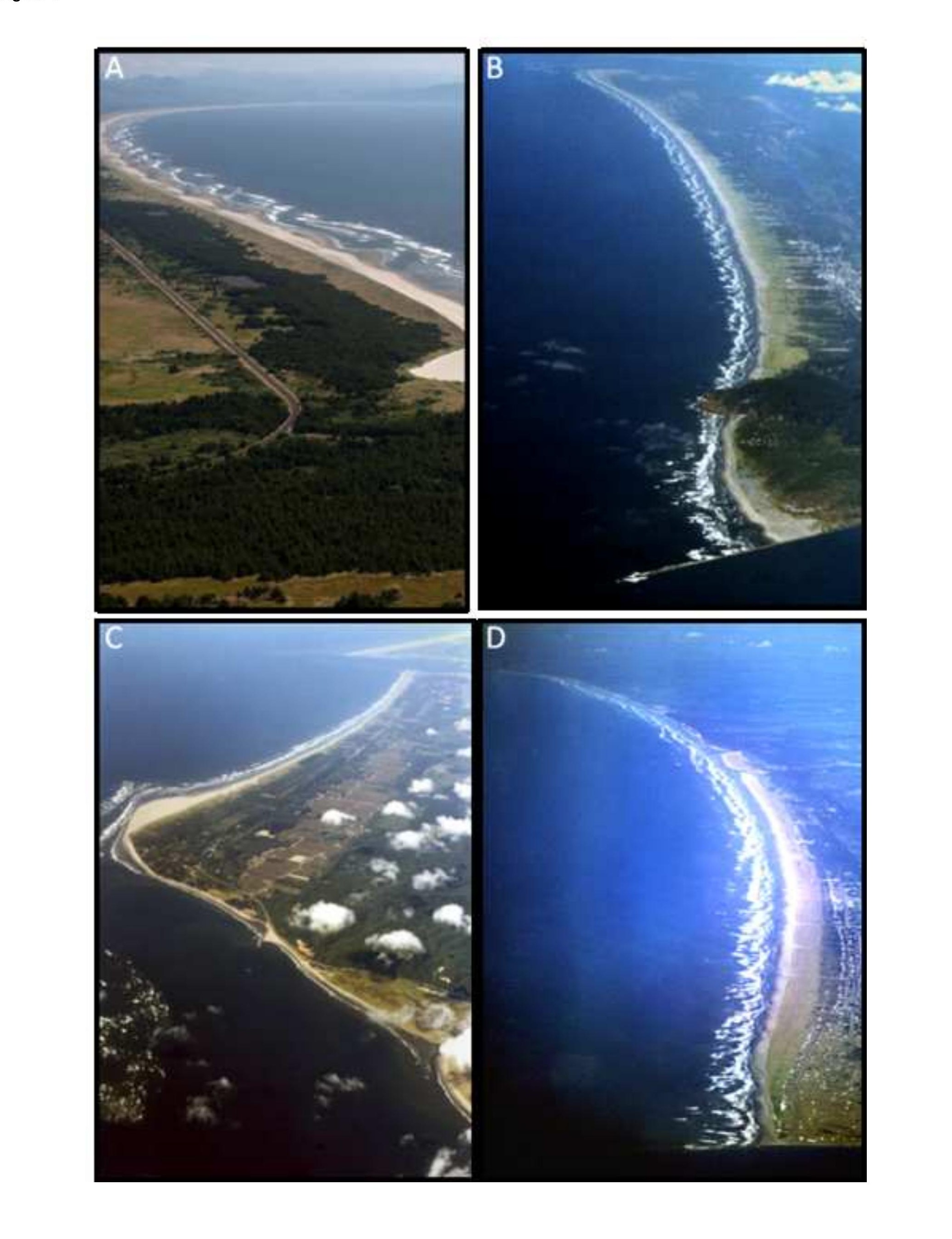

Figure 3

\section{Figure 3}

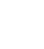

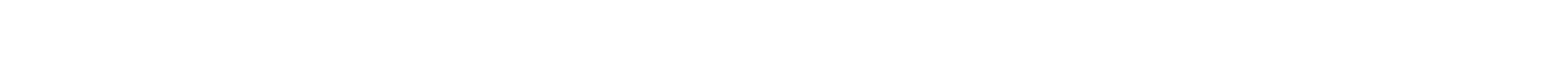

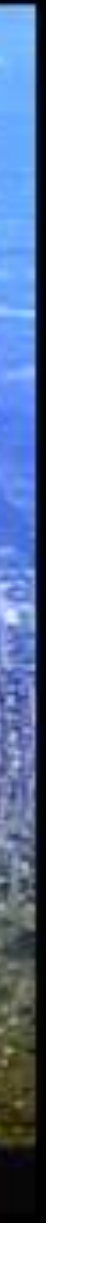



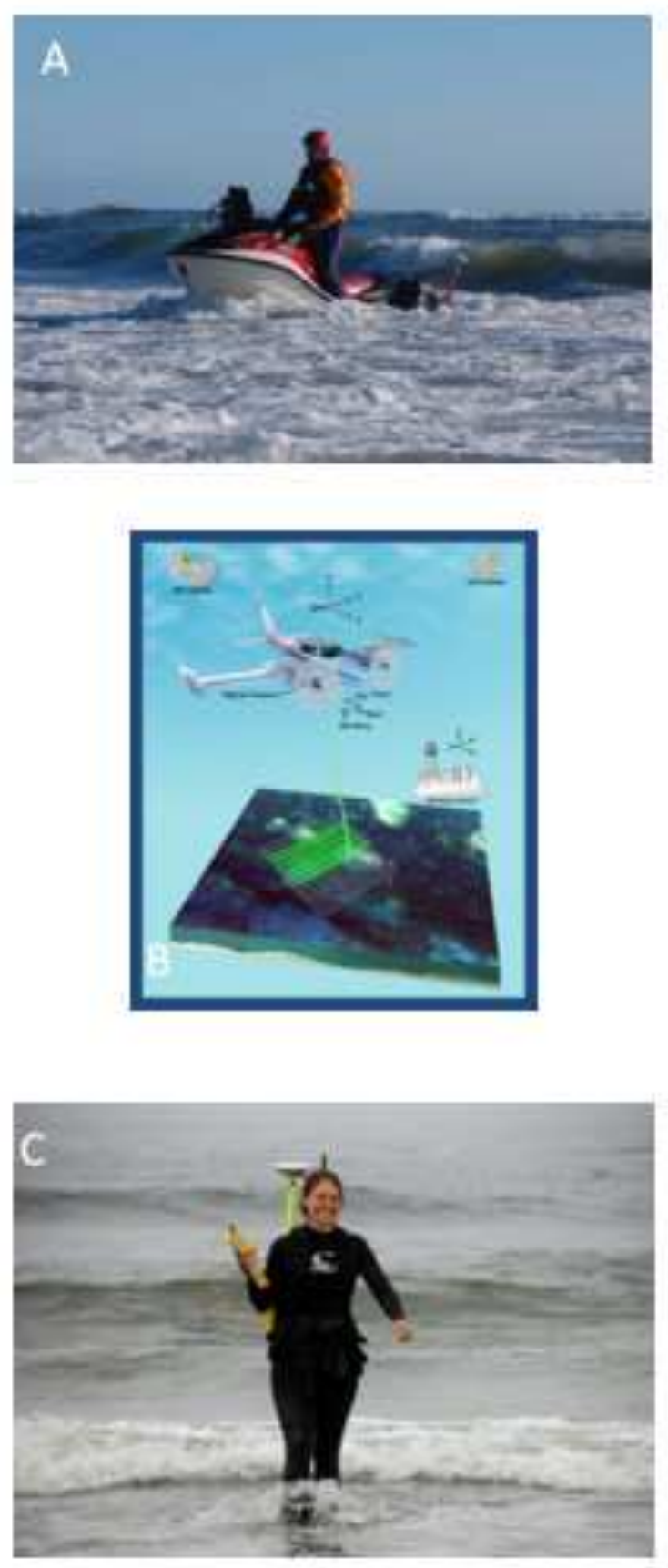

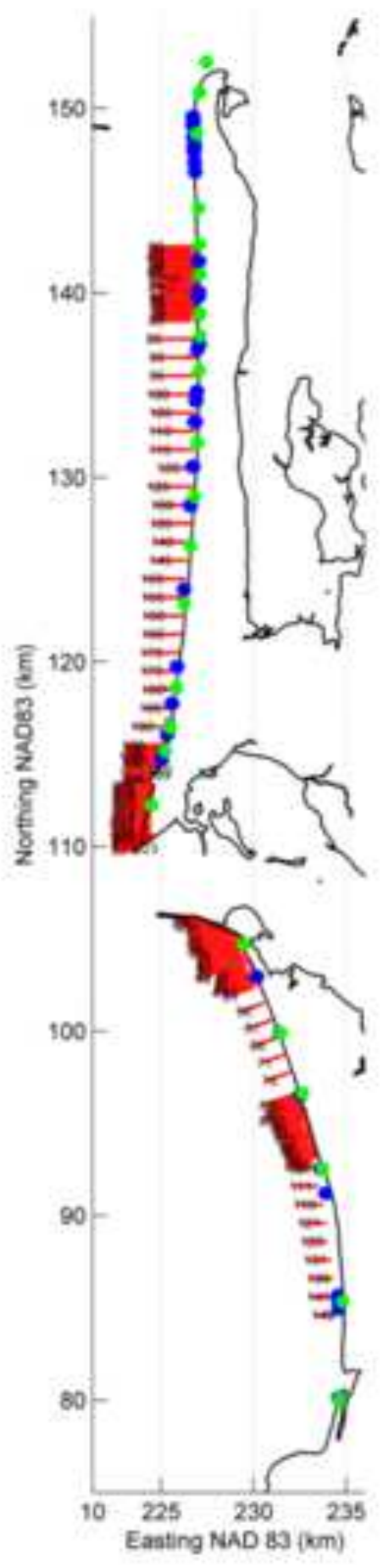

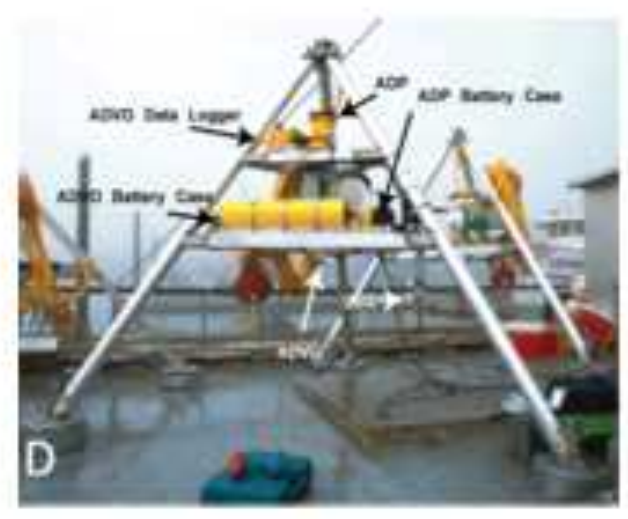
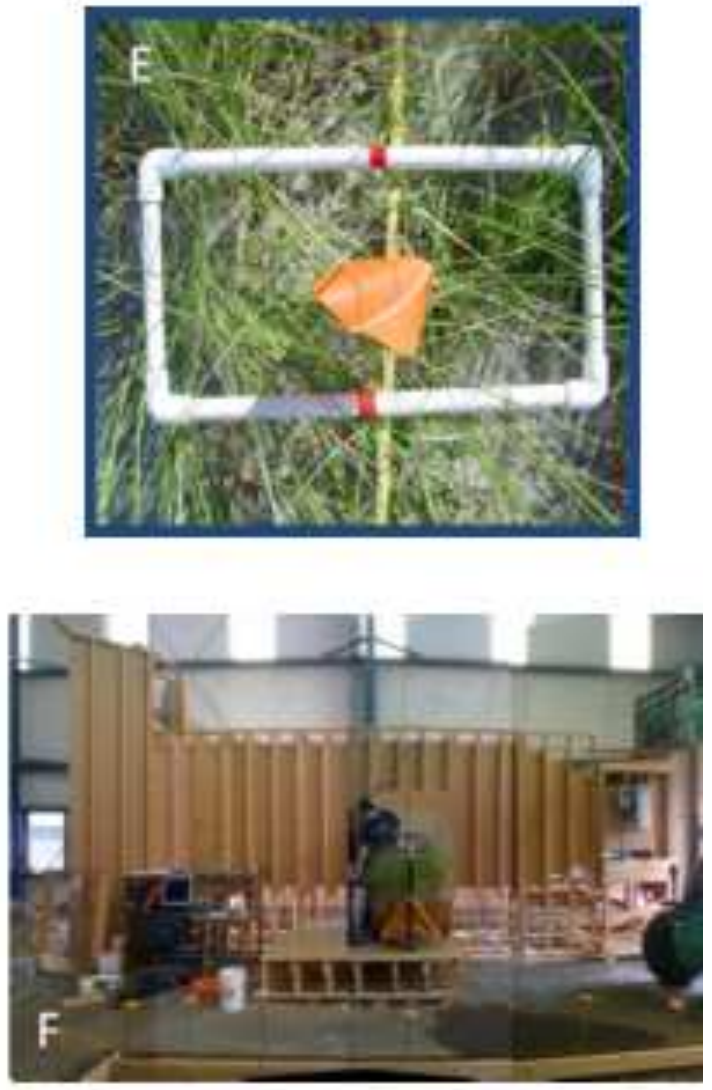


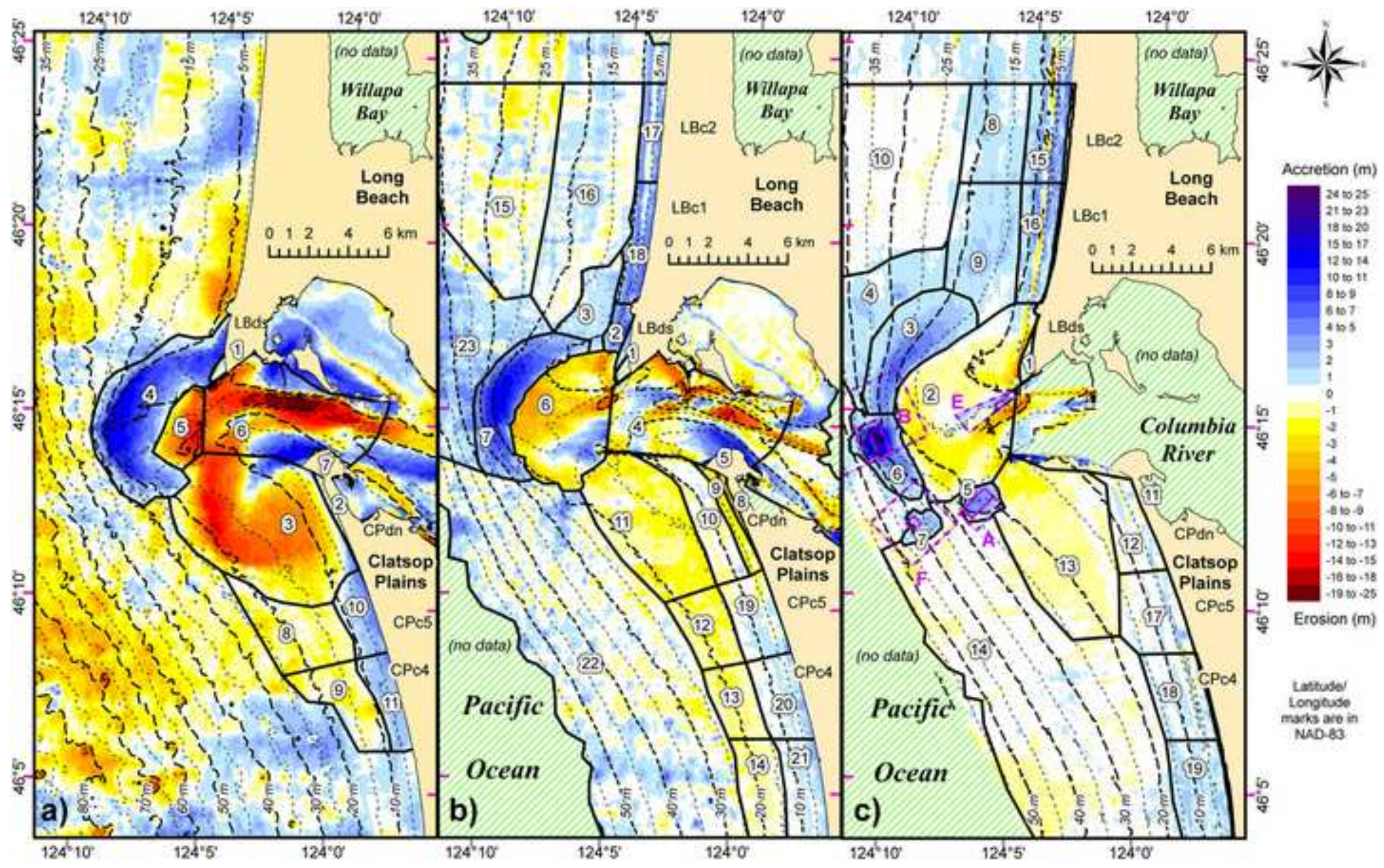




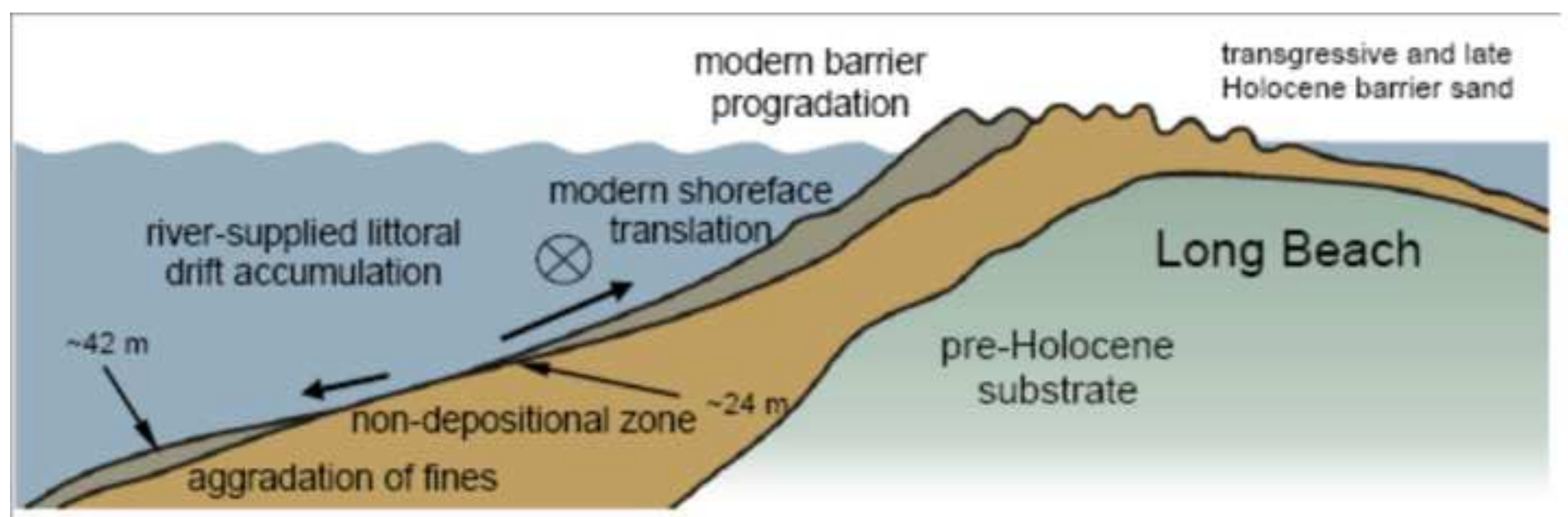

positive contemporary sediment supply and partially overfull accommodation space

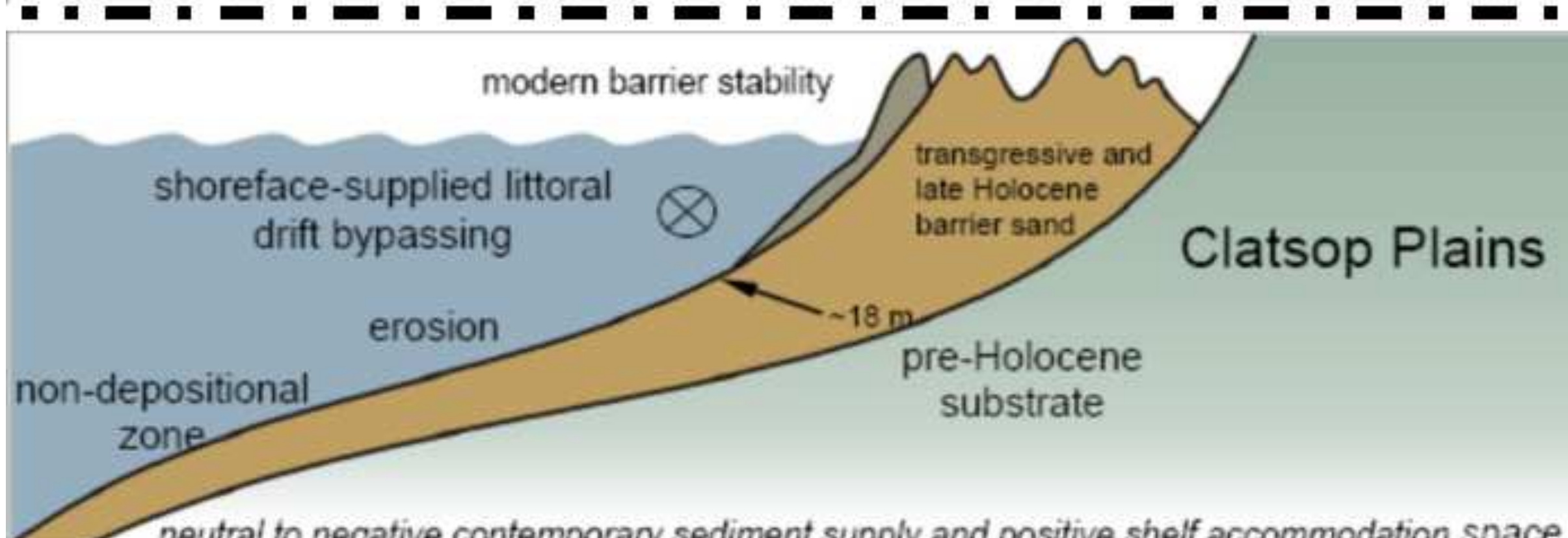

neutral to negative contemporary sediment supply and positive shelf accommodation space 


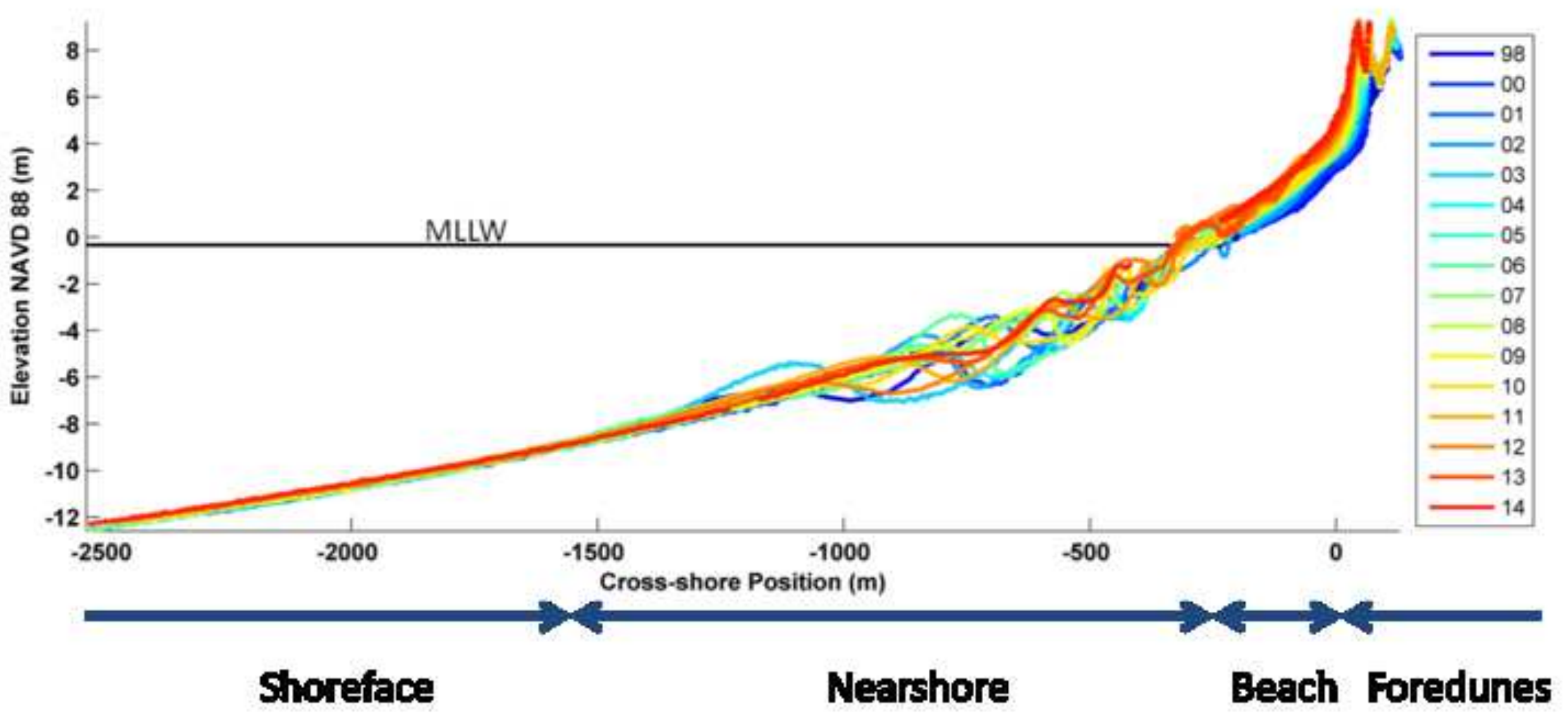

-

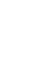

.

Nearshore

Beach Foredunes 

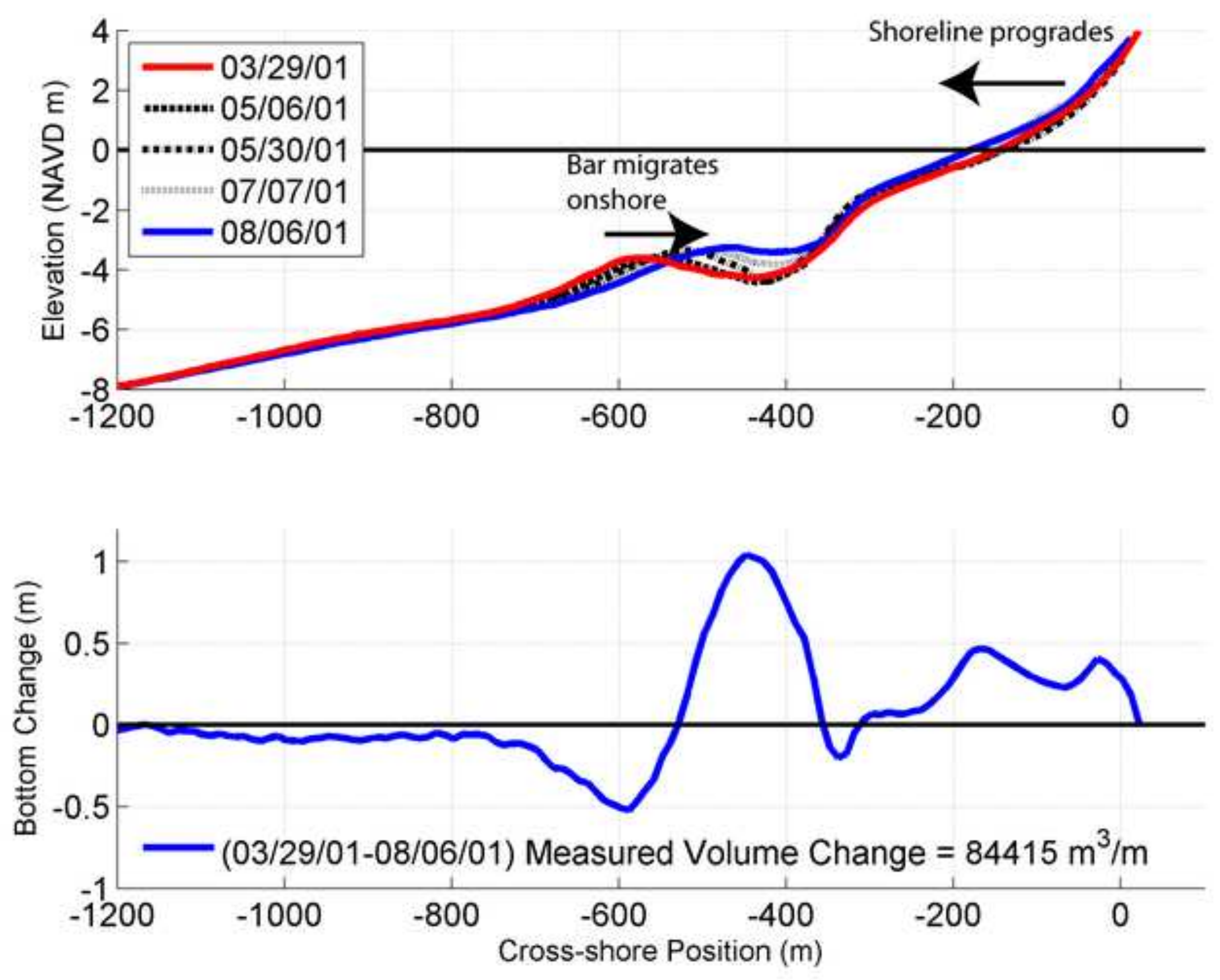

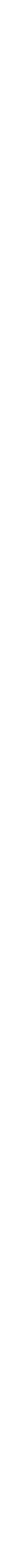

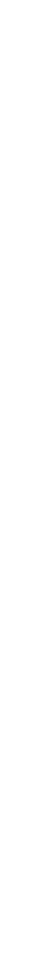

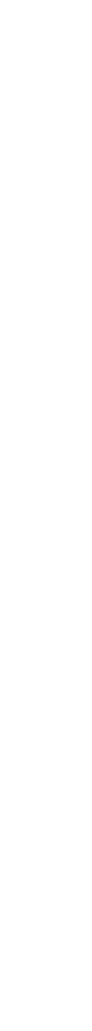



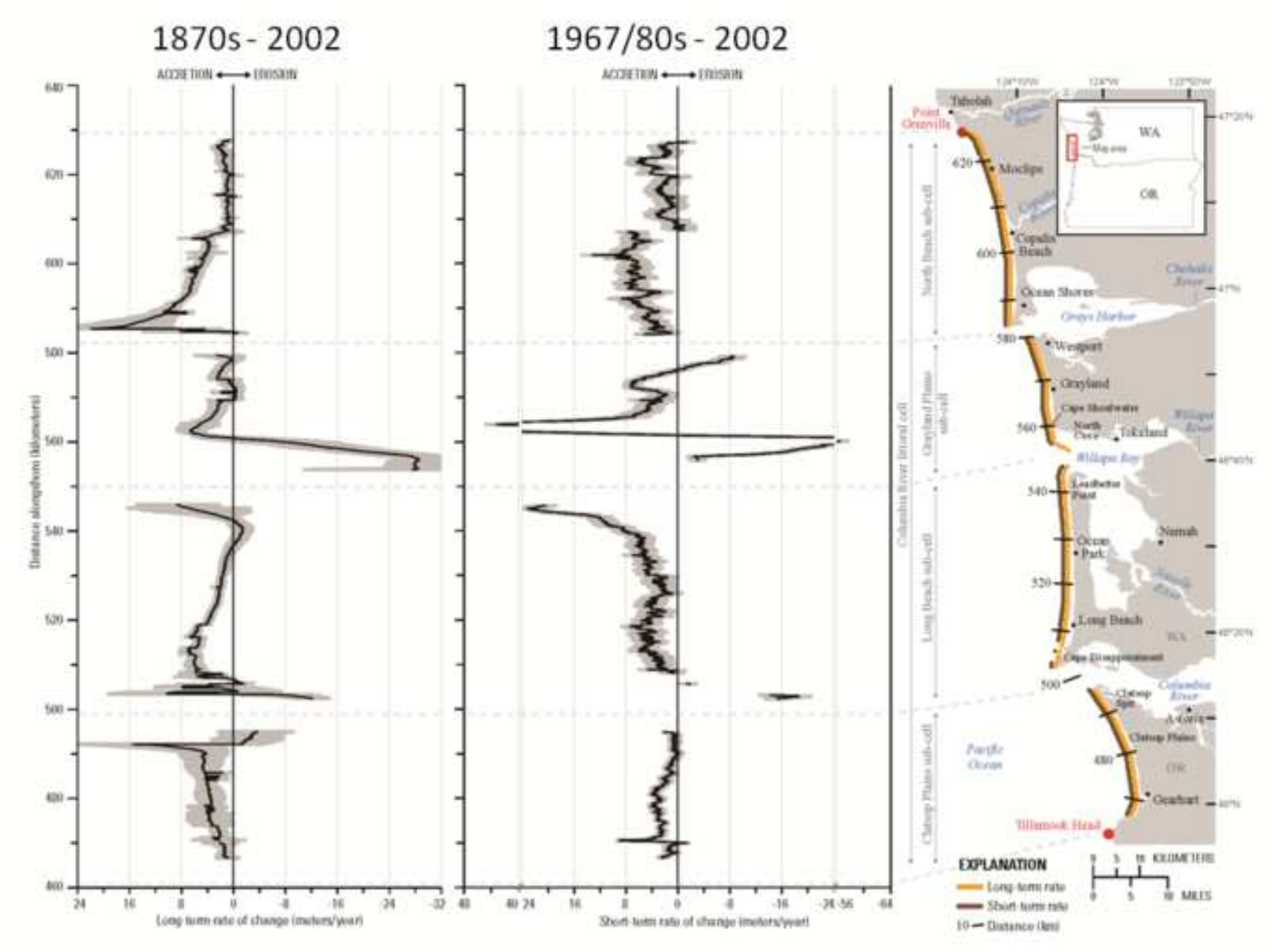


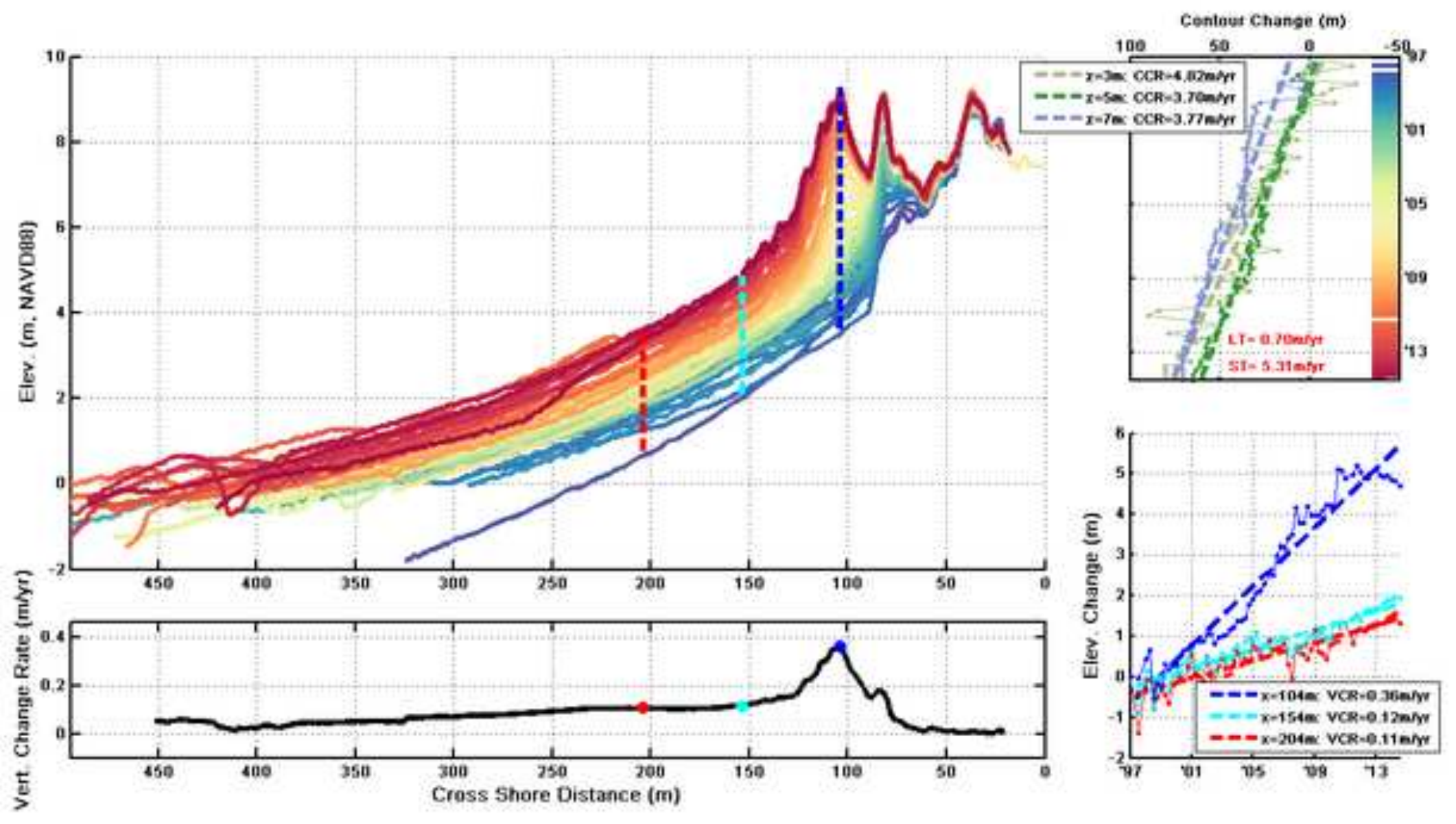




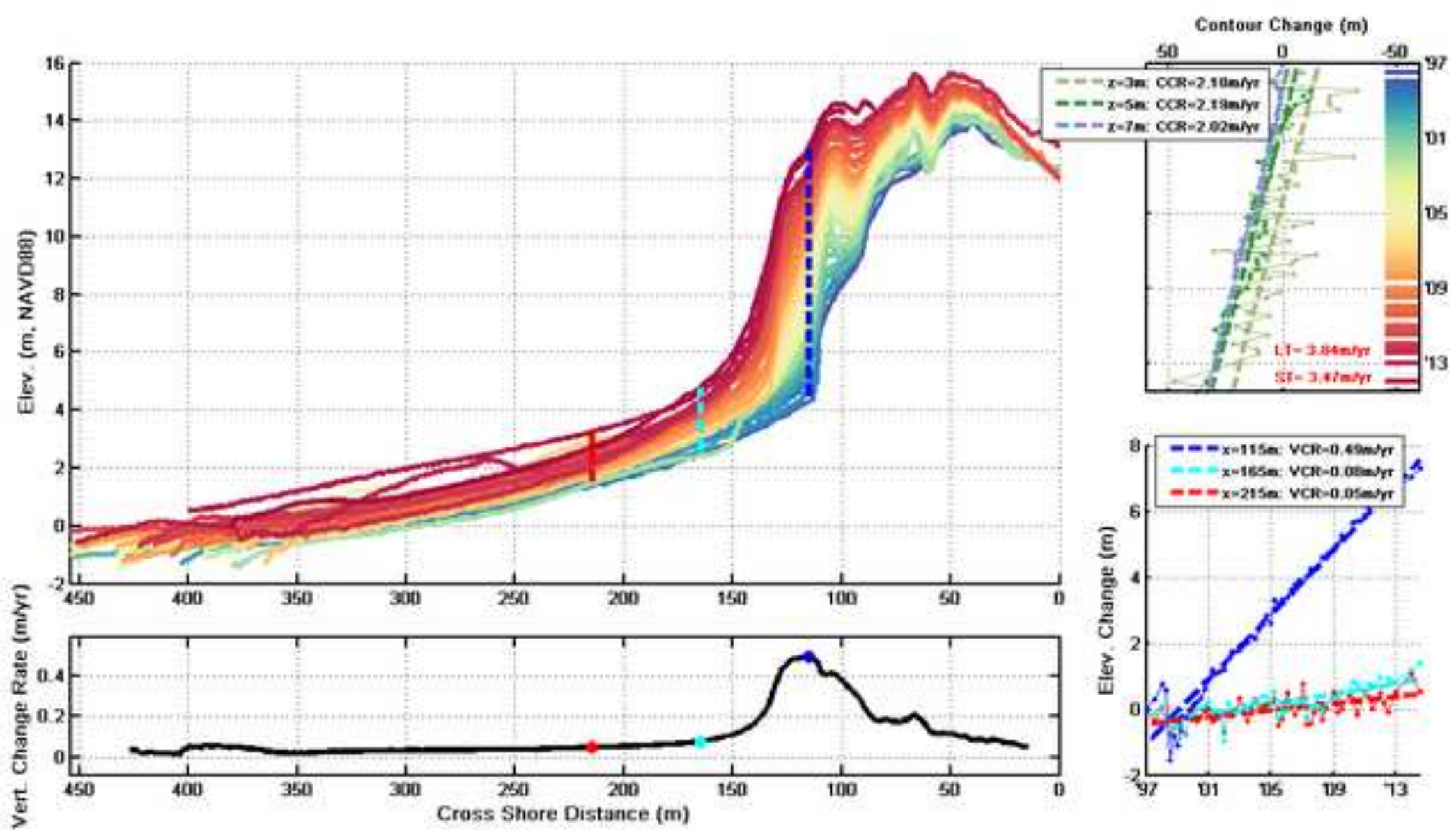




\section{Figure 13}

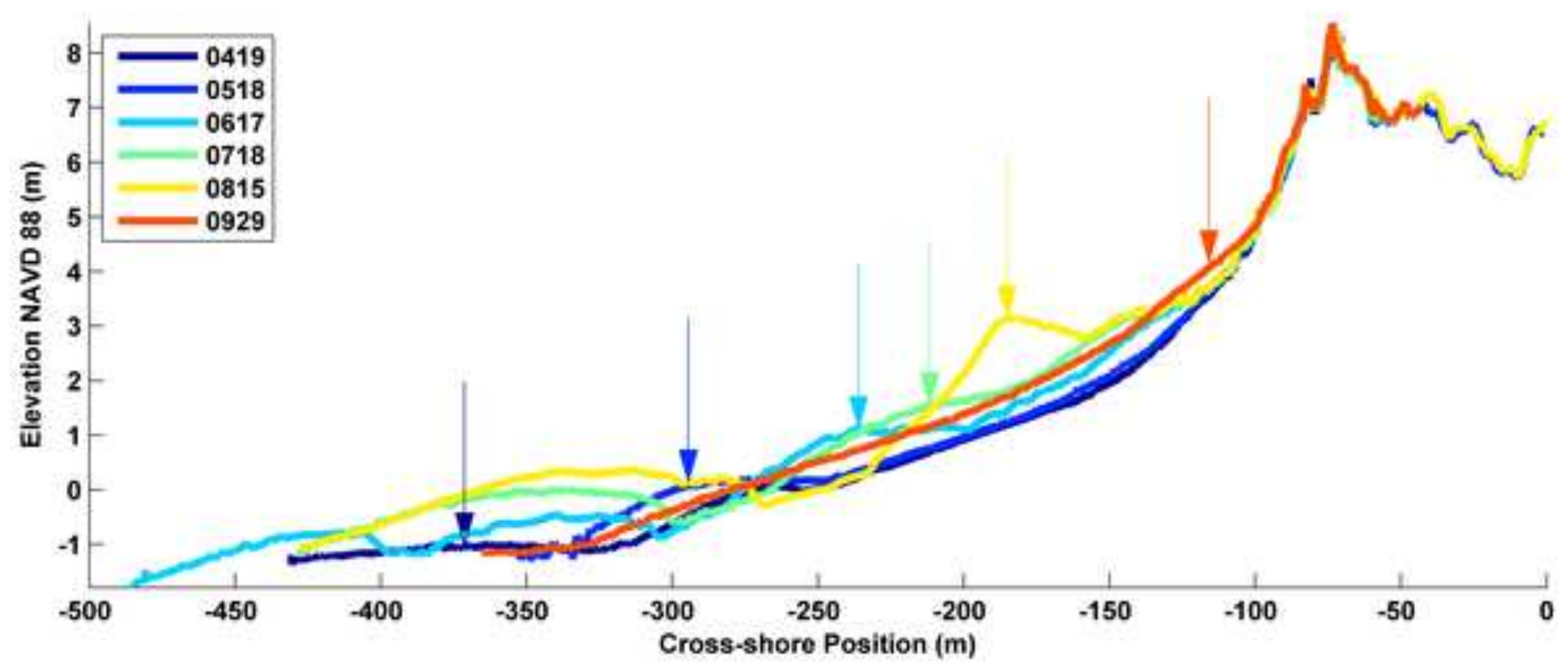


Figure 14
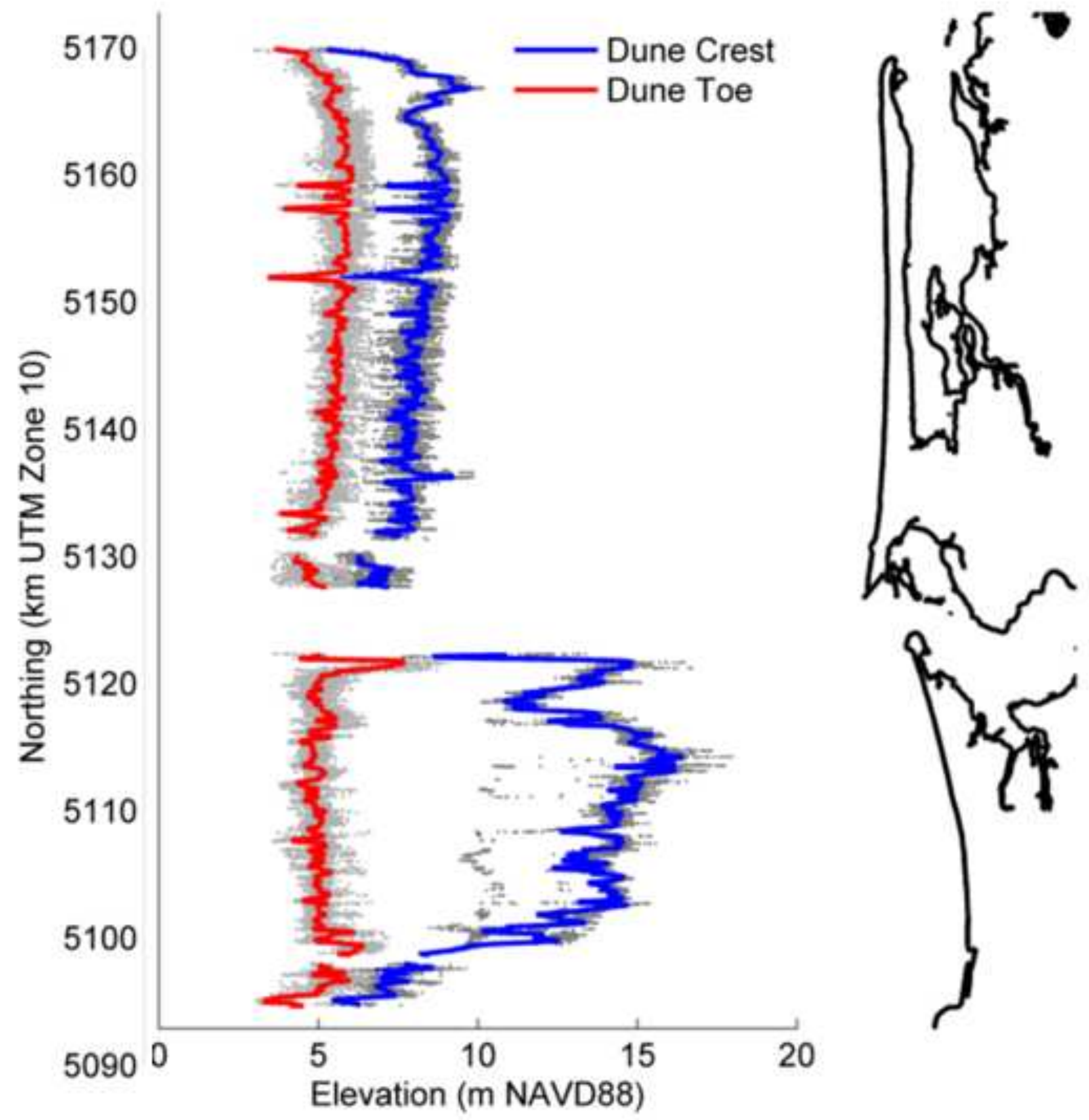

Elevation (m NAVD88) 

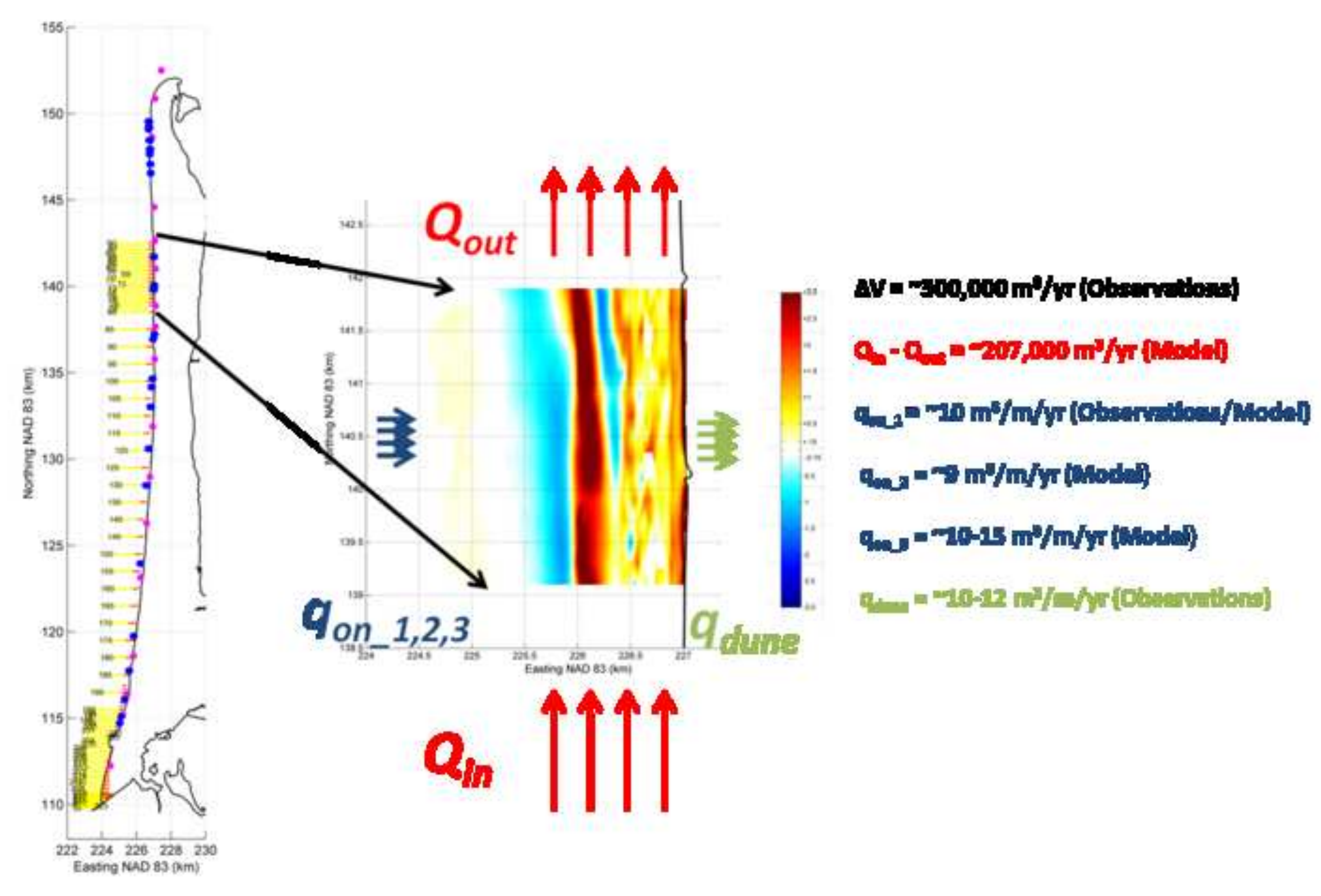

C




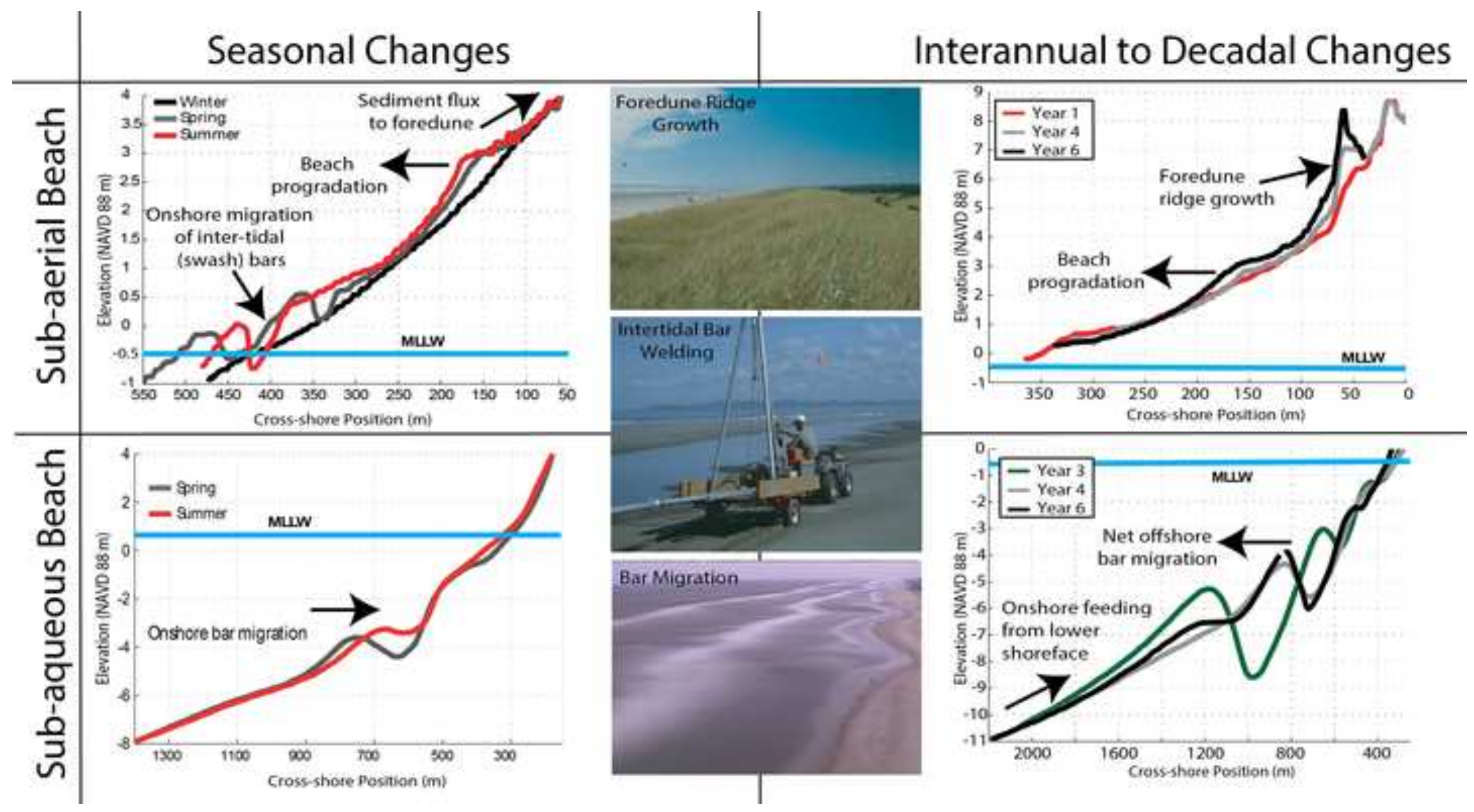




\section{Tables}

2

3 Table 1. Littoral cell averaged shoreline change rates (and ranges) along two of the four sub-

4 cells of the CRLC.

\begin{tabular}{|c|c|c|c|c|}
\hline & Late Prehistoric & Historic & Late Historic & Modern Interannual \\
Sub-cell & $(1700-1870 \mathrm{~s})$ & $(1870 \mathrm{~s}-2002)$ & $(1967-, 1980 \mathrm{~s}-2002)$ & $(1997-2014)$ \\
& $\mathrm{m} / \mathrm{yr}$ & $\mathrm{m} / \mathrm{yr}$ & $\mathrm{m} / \mathrm{yr}$ & $\mathrm{m} / \mathrm{yr}$ \\
\hline Clatsop Plains, OR & $1.4(0.9$ to 2.2$)$ & $3.1(-3.6$ to 15.5$)$ & $1.9(-1.4$ to 9.0$)$ & $1.1(-2.2$ to 2.6$)$ \\
\hline Long Beach, WA & $1.3(0.3$ to 7.1$)$ & $2.6(-12.1$ to 10.3$)$ & $4.7(-18.7$ to 23.2$)$ & $3.7(-2.7$ to 12.5$)$ \\
\hline
\end{tabular}

5 